\title{
Variation in Discosauriscus austriacus (Makowsky, 1876) from the Lower Permian of the Boskovice Furrow (Gzech Republic)
}

\author{
JOZEF KLEMBARA \\ Faculty of Natural Sciences, Comenius University, Zoological Institute, Mlynská dolina \\ B-2, 84215 Bratislava, Slovakia
}

AND

MARIÁN JANIGA National Park High Tatras, Research Station, 05960 Tatranská Lomnica,
Slovakia

Received March 1992, accepted for publication Oclober 1992

Two genera and four species of discosauriscids, Discosauriscus potamites, D. pulcherrimus, Letoverpeton austriacum and $L$. moravicum, have previously been described from the Boskovice Furrow in Moravia. These taxa were differentiated primarily on the basis of proportional differences of the skull together with other morphological characters.

Excavations at two localities in the Boskovice Furrow have produced new, relatively abundant, skeletal material. The specimens are preserved three-dimensionally. In order to cvaluate the differences in skull proportions, 17 variable characters on 70 skulls were measured. Statistical analysis demonstrates the existence of several morphological trends in the shape of the skull. However, no trend permits the division of this set of specimens into two clearly differentiated groups. The morphological differences used previously to define genera and species seem to be incorrect. Pending the discovery of distinct morphological differences, the Moravian discosauriscids can be considered as belonging to only one taxon: Discosauriscus austriacus (Makowsky, 1876).

ADDITIONAL KEY WORDS:-Tetrapoda - discosauriscids' cranial measurements morphometrics - taxonomy.

\section{CONTENTS}

Introduction

Material

Measurements and methods

Statistical analyses: results

Discussion

Acknowledgements

References

Abbreviations used in figures 


\section{INTRODUCTION}

Discosauriscids are relatively abundant members of the Eurasian Permian tetrapod fauna. According to Heaton (1980; cf. Holmes, 1984), their systematic position is unclear. Most authors, however, consider that they are representatives of the Seymouriamorpha (e.g. Romer, 1947; Špinar, 1952; Smithson, 1985; Ivakhnenko, 1987; Werneburg, 1989).

According to Ivakhnenko (1987) the discosauriscids are represented by three genera: Discosauriscus Kuhn, 1933, Ariekanerpeton Ivakhnenko, 1981 and Utegenia Kuznetsov \& Ivakhnenko, 1981, forming the family Discosauriscidae Romer, 1947. Spinar (1952) described new material from localities in the Boskovice Furrow. In addition to Discosauriscus, Špinar also described the new genus Leloverpeton, which differs in the proportions of its skull from the former; each genus comprises two species: D. pulcherrimus (Fritsch, 1879), D. potamiles (Steen, 1938), L. moravicum (Fritsch, 1883) and L. austriacum (Makowsky, 1876). These conclusions were not accepted by Ivakhnenko (1981, 1987), who regarded the differences between these genera only as a result of compressional deformation; he considered all Moravian discosauriscids to be one species: Discosauriscus austriacus (Makowsky, 1876). Werneburg (1985, 1988, 1989), in a review of the German discosauriscids, accepted Spinar's (1952) conclusions (with the exception of D. potamites) and described a new species L. thuringiacum (Werneburg, 1988).

\section{MA'TERIAL}

Two localities of the Boskovice Furrow provided three-dimensionally preserved material of discosauriscids (Klembara \& Meszároš, 1992). The material was chemically prepared and consequently the skulls could be readily measured.

The following is a list of Discosauriscus specimens (D-locality Drválovice, $\mathrm{K}$-locality Kochov) used in this paper (except for the specimens used for the skull measurements used in Table 1; this material will be described in detail in future papers dealing with morphology):

D 20,45, 73, 74, 80, 81, 100, 106, K 9, 14, 16-skulls only; K 20-skull, incomplete shoulder girdle and a few presacral vertebrae; $\mathrm{K} 58$-partial skull and a few postcranial remains; K 74-skull; K 83-skull with a few postcranial elements; K 323 -skull and relatively complete postcranial skeleton; K 328-skull and postcranial skeleton, K 337, 338.I, 339-skulls and articulated postcranial skeletons; K 341.I-skull and almost complete postcranial skeleton; K 346.I, 347-skulls and articulated postcranial skeletons.

\section{MEASUREMENTS AND METHODS}

Measurements. For the computer calculation, 14 characters (variables) were measured to an accuracy of $0.5 \mathrm{~mm}$ on 70 skulls (Fig. 1; Table 1). The next three characters, 15, 16 and 17 are totals of some of the characters (see Table 1). All 17 (i.e. $14+3$ ) characters were present. Some explanatory notes concerning these skull measurements follow.

(1) Individual characters were measured only on the ornamented surfaces of 


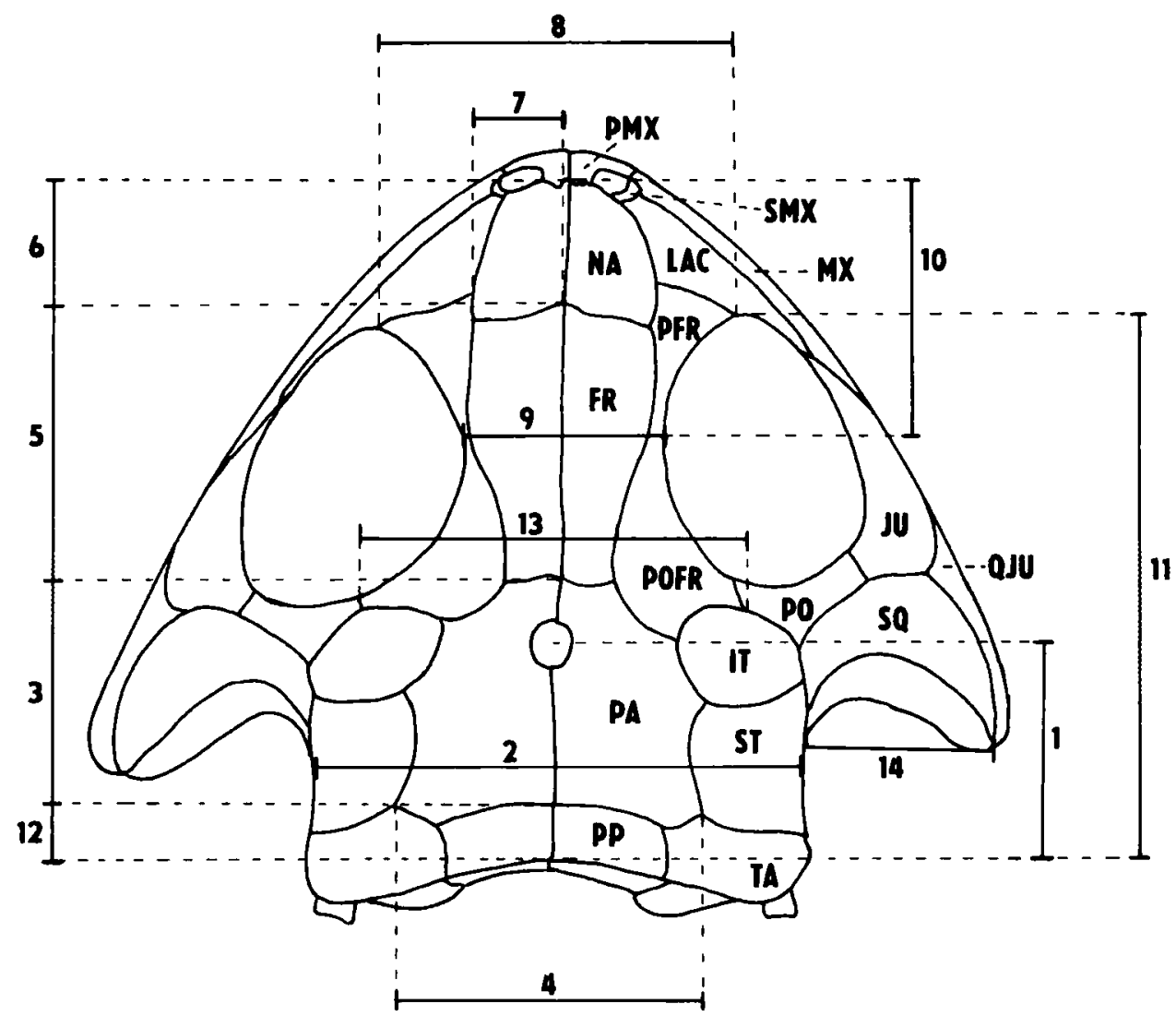

Figure 1. Diagram to illustrate Discosauriscus skull measurements; 14 characters (variables; cf. Table 1 and 'Measurements and methods'). (For key to abbreviations see p. 270.)

the dermal bones. Whenever possible, the total lengths were obtained by the total of individual bones (to eliminate the possible gaps between them caused by greater or lesser compression).

(2) It was not possible to measure the midline length (snout-tip-postparietal) because the premaxillary is mostly absent or displaced from its original position by varying degrees of compression. In the more strongly pressure-deformed skulls found at other localities in the Boskovice Furrow (Spinar, 1952), the exact measurements of some lengths is impossible. Therefore the measurements used by Špinar (1952) (e.g. 'length of skull', 'width of skull', 'middle height of orbit') are omitted. Moreover, such material has been mostly found on the bedding planes of split shale (i.e. not as fully preserved positives and negatives), which can prevent correct determination of the real shape of bone, or the differentiation of ornamented from unornamented surface. Also, in the new three-dimensional matcrial from Drválovice and Kochov, the lateral portion of the orbit is almost always disturbed.

(3) The length of the parietal is taken to be the distance between its anteromedial and posteromedial edge. The width of the parietals is the distance of their posterolateral edges (i.e. in the region of the junction of the parietal with the tabular and supratemporal). The lengths of the postparietal, frontal and nasal were measured in the same way as the length of the parietal. 
TABLE 1. Discosauriscus austriacus skull

\begin{tabular}{|c|c|c|c|c|c|c|c|c|c|}
\hline \multirow[b]{2}{*}{$\begin{array}{l}\text { Specimen } \\
\text { number }\end{array}$} & & \multicolumn{8}{|r|}{ Character } \\
\hline & & $\begin{array}{c}\text { Parietal } \\
\text { foramen- } \\
\text { postparietal }\end{array}$ & $\begin{array}{c}\text { V2 } \\
\text { Width of } \\
\text { skull table } \\
\text { at mid-supra } \\
\text { temporal }\end{array}$ & $\begin{array}{l}\text { Length of } \\
\text { parietal }\end{array}$ & $\begin{array}{l}\text { Width of } \\
\text { parietals }\end{array}$ & $\begin{array}{l}\text { Length of } \\
\text { frontal }\end{array}$ & $\begin{array}{l}\text { Length of } \\
\text { nasal }\end{array}$ & $\begin{array}{c}\text { Width of } \\
\text { nasal }\end{array}$ & $\begin{array}{c}\text { V8 } \\
\text { Connecting } \\
\text { line of } \\
\text { lateral tips } \\
\text { of } \\
\text { prefrontals }\end{array}$ \\
\hline $\mathrm{K} \mathbf{l}$ & 1 & 10.0 & 26.5 & 11.0 & 8.5 & 11.0 & 8.0 & 4.5 & 18.5 \\
\hline K5 & 2 & 7.5 & 20.0 & 8.0 & 12.5 & 10.0 & 6.0 & 4.0 & 16.0 \\
\hline K9 & 3 & 8.0 & 24.5 & 8.0 & 13.5 & 9.5 & 6.0 & 4.0 & 16.0 \\
\hline K 13 & 4 & 9.0 & 21.5 & 9.0 & 13.5 & 10.5 & 5.0 & 4.0 & 15.0 \\
\hline $\mathrm{K} 14$ & 5 & 9.5 & 29.0 & 9.5 & 19.0 & 11.5 & 7.0 & 4.0 & 17.0 \\
\hline K 17 & 6 & 5.0 & 23.0 & 8.0 & 14.0 & 9.0 & 5.0 & 4.0 & 14.5 \\
\hline K18 & 7 & 9.0 & 23.5 & 9.5 & 14.0 & 9.5 & 6.5 & 4.5 & 14.0 \\
\hline K20 & 8 & 9.0 & 24.5 & 8.5 & 14.5 & 11.0 & 7.0 & 5.0 & 17.0 \\
\hline K31 & 9 & 7.5 & 18.0 & 8.5 & 11.5 & 9.5 & 5.5 & 3.5 & 13.0 \\
\hline K36 & 10 & 8.0 & 21.5 & 8.5 & 14.0 & 10.0 & 7.0 & 4.0 & 14.0 \\
\hline $\mathrm{K} 40$ & 11 & 10.0 & 27.0 & 10.5 & 16.0 & 13.0 & 7.5 & 4.0 & 16.0 \\
\hline K47 & 12 & 9.0 & 23.5 & 10.0 & 15.0 & 10.0 & 7.0 & 4.0 & 17.0 \\
\hline K49 & 13 & 9.5 & 25.0 & 11.0 & 16.0 & 10.5 & 6.0 & 4.5 & 18.5 \\
\hline K50.I & 14 & 8.5 & 21.5 & 9.0 & 13.0 & 9.5 & 5.5 & 3.5 & 14.0 \\
\hline K54 & 15 & 12.0 & 28.0 & 13.5 & 18.5 & 16.0 & 11.5 & 5,0 & 23.0 \\
\hline K55 & 16 & 9.0 & 23.0 & 8.0 & 14.0 & 10.0 & 8.5 & 4.0 & 16.0 \\
\hline K57 & 17 & 9.0 & 24.0 & 9.0 & 14.5 & 10.5 & 7.0 & 4.0 & 13.0 \\
\hline K60 & 18 & 9.0 & 22.0 & 11.0 & 14.0 & 10.5 & 7.0 & 4.0 & 17.5 \\
\hline K64 & 19 & 8.5 & 22.0 & 9.0 & 15.0 & 9.0 & 6.0 & 3.5 & 14.5 \\
\hline K69 & 20 & 9.0 & 25.0 & 11.0 & 14.0 & 11.5 & 7.0 & 4.5 & 16.5 \\
\hline K72 & 21 & 8.5 & 24.0 & 9.0 & 15.5 & 11.5 & 8.0 & 4.5 & 18.0 \\
\hline K83 & 22 & 8.5 & 22.5 & 8.5 & 14.5 & 11.5 & 7.0 & 3.5 & 14.5 \\
\hline K84 & 23 & 9.0 & 27.0 & 10.0 & 16.0 & 10.5 & 6.5 & 4.0 & 16.5 \\
\hline K98 & 24 & 8.5 & 22.0 & 8.5 & 14.0 & 10.0 & 5.5 & 4.0 & 13.5 \\
\hline K99 & 25 & 9.0 & 22.0 & 9.0 & 14.5 & 10.0 & 4.5 & 4.0 & 15.5 \\
\hline K 100 & 26 & 7.5 & 20.0 & 7.5 & 12.0 & 8.5 & 5.0 & 4.0 & 15.0 \\
\hline K 102 & 27 & 8.5 & 27.0 & 10.0 & 17.0 & 10.0 & 8.0 & 4.5 & 16.5 \\
\hline $\mathbf{K} \backslash 13$ & 28 & 8.0 & 26.5 & 8.0 & 17.0 & 11.0 & 7.0 & 4.0 & 16.0 \\
\hline K 172 & 29 & 11.5 & 27.5 & 12.5 & 17.5 & 11.5 & 8.5 & 5.5 & 19.5 \\
\hline K 194 & 30 & 7.5 & 22.5 & 8.0 & 14.5 & 10.0 & 6.5 & 4.0 & 15.0 \\
\hline K206 & 31 & 9.0 & 25.0 & 10.0 & 15.5 & 10.5 & 7.0 & 3.5 & 15.0 \\
\hline K208 & 32 & 8.0 & 23.0 & 9.0 & 13.5 & 9.5 & 5.5 & 4.5 & 15.0 \\
\hline D4 & 33 & 10.0 & 22.0 & 11.0 & 14.5 & 10.0 & 7.0 & 4.0 & 14.0 \\
\hline D7 & 34 & 8.0 & 24.0 & 8.0 & 14.0 & 9.0 & 6.0 & 4.0 & 19.5 \\
\hline D9 & 35 & 9.0 & 22.5 & 8.5 & 14.5 & 11.0 & 6.0 & 4.0 & 19.0 \\
\hline D20 & 36 & 10.5 & 24.5 & 13.0 & 15.5 & 12.5 & 7.0 & 3.5 & 16.0 \\
\hline D22 & 37 & 9.5 & 28.5 & 9.5 & 17.5 & 10.0 & 7.0 & 5.0 & 19.0 \\
\hline D39 & 38 & 8.5 & 27.5 & 10.0 & 18.0 & 10.5 & 7.0 & 4.5 & 18.5 \\
\hline D40 & 39 & 8.0 & 27.0 & 8.5 & 18.5 & 12.0 & 5.5 & 4.5 & 18.5 \\
\hline D42 & 40 & 10.0 & 27.0 & 9.5 & 16.0 & 12.0 & 7.0 & 4.5 & 15.0 \\
\hline D53 & 41 & 10.5 & 26.5 & 10.5 & 16.0 & 12.0 & 7.5 & 5.0 & 20.0 \\
\hline D6l & 42 & 8.5 & 23.0 & 8.5 & 15.5 & 10.5 & 6.0 & 4.0 & 15.0 \\
\hline D64 & 43 & 7.5 & 25.0 & 8.0 & 14.5 & 10.0 & 6.0 & 4.0 & 13.5 \\
\hline D69 & 44 & 8.5 & 30.0 & 11.0 & 16.0 & 11.0 & 7.5 & 5.0 & 17.5 \\
\hline D70 & 45 & 9.0 & 27.5 & 10.5 & 17.0 & 9.0 & 7.0 & 5.0 & 19.0 \\
\hline D72 & 46 & 9.5 & 27.0 & 9.5 & 16.5 & 12.0 & 6.0 & 5.0 & 18.0 \\
\hline D73 & 47 & 9.0 & 23.5 & 10.0 & 15.0 & 10.5 & 6.5 & 4.5 & 16.0 \\
\hline D74 & 48 & 11.0 & 27.0 & 11.0 & 16.5 & 11.5 & 7.0 & 5.0 & 20.0 \\
\hline D76 & 49 & 10.0 & 32.5 & 10.5 & 21.0 & 10.0 & 6.5 & 5.0 & 20.0 \\
\hline D82 & 50 & 7.5 & 27.0 & 10.0 & 17.0 & 9.0 & 6.0 & 4.5 & 16.0 \\
\hline D89 & $5 !$ & 8.0 & 31.0 & 9.5 & 18.0 & 10.0 & 6.5 & 5.0 & 19.5 \\
\hline D91 & 52 & 10.0 & 28.0 & 12.0 & 17.0 & 13.5 & 9.0 & 6.0 & 20.5 \\
\hline D94 & 53 & 9.0 & 33.0 & 10.0 & 20.0 & 11.0 & 7.0 & 5.0 & 19.5 \\
\hline Dl00 & 54 & 10.0 & 30.0 & 10.0 & 20.0 & 11.0 & 7.0 & 4.5 & 18.0 \\
\hline
\end{tabular}


measurements (in mm) (cf. Fig. 1)

\begin{tabular}{|c|c|c|c|c|c|c|c|c|}
\hline riables & & & & & & & & \\
\hline $\begin{array}{l}\text { Interorbital } \\
\text { width }\end{array}$ & $\begin{array}{c}\mathrm{V} 10 \\
\text { Connecting } \\
\text { line of } \\
\text { level } 9 \dagger- \\
\text { nasal }\end{array}$ & $\begin{array}{l}\text { VIl } \\
\text { Connecting } \\
\text { line of } \\
\text { orbitł- } \\
\text { postparietal }\end{array}$ & $\begin{array}{l}\text { Length of } \\
\text { postparietal }\end{array}$ & $\begin{array}{c}V 13 \\
\text { Connecting } \\
\text { line of } \\
\text { lateral tips } \\
\text { of } \\
\text { postfrontals }\end{array}$ & Squamosum§ & $\begin{array}{c}\text { Total of } \\
\begin{array}{c}12+3+ \\
5+6\end{array}\end{array}$ & $\begin{array}{c}\text { Total of } \\
12+3\end{array}$ & $\begin{array}{c}\text { Total of } \\
5+6\end{array}$ \\
\hline 12.5 & 13.0 & 26.5 & 2.5 & 19.0 & 11.0 & 22.5 & 13.5 & 19.0 \\
\hline 7.5 & 11.5 & 21.0 & 2.5 & 14.0 & 8.5 & 26.5 & 10.5 & 16.0 \\
\hline 11.5 & 10.0 & 21.0 & 2.0 & 16.5 & 9.0 & 25.5 & 10.0 & 15.5 \\
\hline 9.0 & 10.5 & 22.5 & 2.5 & 16.0 & 8.5 & 27.0 & 11.5 & 15.5 \\
\hline 12.0 & 14.0 & 26.0 & 3.0 & 18.5 & 10.0 & 30.0 & 11.5 & 18.5 \\
\hline 9.0 & 10.0 & 11.0 & 3.0 & 15.5 & 8.5 & 25.0 & 11.0 & 14.0 \\
\hline 10.0 & 12.5 & 23.5 & 2.5 & 24.0 & 10.0 & 28.0 & 12.0 & 16.0 \\
\hline 11.0 & 13.5 & 23.5 & 2.0 & 19.0 & 11.0 & 28.5 & 10.5 & 18.0 \\
\hline 7.5 & 10.0 & 20.0 & 2.0 & 12.0 & 8.0 & 25.5 & 10.5 & 15.0 \\
\hline 9.5 & 15.0 & 23.0 & 2.0 & 14.5 & 7.0 & 27.5 & 10.5 & 17.0 \\
\hline 11.5 & 15.5 & 29.0 & 1.5 & 18.5 & 10.5 & 32.5 & 12.0 & 20.5 \\
\hline 10.5 & 13.5 & 28.0 & 1.5 & 19.5 & 9.5 & 18.5 & 11.5 & 17.0 \\
\hline 10.5 & 12.5 & 23.0 & 2.5 & 20.0 & 11.5 & 30.0 & 13.5 & 16.5 \\
\hline 9.5 & 11.5 & 24.5 & 2.0 & 16.0 & 9.0 & 26.0 & 11.0 & 15.0 \\
\hline 12.5 & 19.5 & 35.5 & 2.5 & 22.5 & 12.0 & 42.5 & 16.0 & 26.5 \\
\hline 9.5 & 14.5 & 26.5 & 2.5 & 16.0 & 11.5 & 29.0 & 10.5 & 18.5 \\
\hline 11.5 & 12.0 & 22.5 & 2.0 & 18.0 & 11.0 & 28.5 & 11.0 & 17.5 \\
\hline 9.0 & 12.5 & 25.0 & 2.0 & 15.0 & 10.0 & 30.5 & 13.0 & 17.5 \\
\hline 9.0 & 10.0 & 21.5 & 2.0 & 16.0 & 9.5 & 26.0 & 11.0 & 15.0 \\
\hline 10.0 & 13.5 & 26.0 & 2.5 & 17.0 & 10.0 & 32.0 & 13.5 & 18.5 \\
\hline 12.0 & 14.5 & 26.5 & 1.5 & 17.5 & 9.5 & 30.0 & 10.5 & 19.5 \\
\hline 9.5 & 11.5 & 23.0 & 2.5 & 17.0 & 9.5 & 29.5 & 11.0 & 18.5 \\
\hline 9.5 & 12.5 & 23.5 & 2.5 & 17.5 & 8.5 & 29.5 & 12.5 & 17.0 \\
\hline 9.0 & 8.5 & 22.5 & 2.0 & 18.0 & 8.0 & 26.0 & 10.5 & 15.5 \\
\hline 10.5 & 11.0 & 23.0 & 2.5 & 18.0 & 9.0 & 26.0 & 11.5 & 14.5 \\
\hline 7.5 & 10.5 & 19.0 & 2.0 & 13.0 & 7.0 & 23.0 & 9.5 & 13.5 \\
\hline 9.5 & 12.5 & 26.0 & 2.0 & 19.0 & 9.5 & 30.0 & 12.0 & 18.0 \\
\hline 11.5 & 12.5 & 24.0 & 1.5 & 18.5 & 9.5 & 27.5 & 9.5 & 18.0 \\
\hline 13.0 & 14.5 & 29.5 & 3.0 & 22.0 & 11.5 & 35.5 & 15.5 & 20.0 \\
\hline 9.0 & 12.0 & 21.5 & 2.0 & 15.5 & 10.5 & 26.5 & 10.0 & 16.5 \\
\hline 9.5 & 12.0 & 23.5 & 2.0 & 17.0 & 11.0 & 27.5 & 12.0 & 17.5 \\
\hline 8.5 & 10.5 & 21.5 & 2.0 & 14.0 & 8.5 & 26.0 & 11.0 & 15.0 \\
\hline 10.0 & 12.5 & 25.5 & 2.5 & 16.0 & 6.0 & 30.5 & 13.5 & 17.0 \\
\hline 11.0 & 11.0 & 20.0 & 2.0 & 19.0 & 9.5 & 26.0 & 11.0 & 15.0 \\
\hline 10.0 & 11.0 & 25.0 & 2.5 & 17.0 & 9.0 & 28.0 & 11.0 & 17.0 \\
\hline 11.0 & 13.0 & 30.0 & 2.5 & 18.5 & 8.5 & 35.0 & 15.5 & 19.5 \\
\hline 11.5 & 12.0 & 24.0 & 2.5 & 21.0 & 11.0 & 29.0 & 12.0 & 17.0 \\
\hline 11.0 & 12.5 & 24.5 & 2.5 & 18.5 & 12.0 & 30.0 & 12.5 & 17.5 \\
\hline 11.0 & 12.0 & 24,0 & 2.0 & 20.0 & 11.0 & 28.0 & 10.5 & 17.5 \\
\hline 11.5 & 13.0 & 27.5 & 3.0 & 20.0 & 10.0 & 31.5 & 12.5 & 19.0 \\
\hline 12.0 & 13.5 & 29.0 & 2.0 & 20.0 & 10.0 & 32.0 & 12.5 & 19.5 \\
\hline 9.0 & 12.5 & 22.0 & 2.0 & 16.0 & 9.0 & 27.0 & 10.5 & 16.5 \\
\hline 10.5 & 12.0 & 22.0 & 2.0 & 19.0 & 9.0 & 26.0 & 10.0 & 16.0 \\
\hline 11.5 & 13.0 & 25.0 & 2.0 & 19.0 & 10.0 & 31.5 & 13.0 & 18.5 \\
\hline 11.0 & 13.0 & 24.0 & 2.0 & 21.0 & 11.0 & 28.5 & 12.5 & 16.0 \\
\hline 11.0 & 11.5 & 26.5 & 3.0 & 20.0 & 11.0 & 29.5 & 11.5 & 18.0 \\
\hline 10.0 & 10.0 & 28.0 & 3.0 & 16.0 & 9.0 & 30.0 & 13.0 & 17.0 \\
\hline 10.5 & 14.5 & 30.0 & 3.5 & 19.5 & 10.0 & 33.0 & 14.5 & 18.5 \\
\hline 13.0 & 11.5 & 25.0 & 2.5 & 24.0 & 12.0 & 29.5 & 13.0 & 16.5 \\
\hline 10.5 & 12.0 & 23.0 & 2.5 & 17.5 & 9.0 & 27.5 & 12.5 & 15.0 \\
\hline 12.0 & 12.5 & 23.0 & 1.5 & 19.5 & 9.5 & 28.5 & 12.0 & 16.5 \\
\hline 13.0 & 16.0 & 29.0 & 3.0 & 22.0 & 12.0 & 37.5 & 15.0 & 22.5 \\
\hline 13.0 & 12.5 & 25.0 & 3.0 & 20.0 & 11.5 & 31.0 & 13.0 & 18.0 \\
\hline 11.0 & 14.0 & 25.0 & 2.5 & 20.0 & 11.0 & 30.5 & 12.5 & 18.0 \\
\hline
\end{tabular}


'TABLE 1.

\begin{tabular}{|c|c|c|c|c|c|c|c|c|c|}
\hline \multirow[b]{2}{*}{$\begin{array}{l}\text { Specimen } \\
\text { number }\end{array}$} & & \multicolumn{8}{|r|}{ Characters } \\
\hline & & $\begin{array}{c}\text { Parietal } \\
\text { foramen- } \\
\text { postparietal }\end{array}$ & $\begin{array}{c}\mathrm{V} 2 \\
\text { Width of } \\
\text { skull table } \\
\text { at mid-supra } \\
\text { temporal }\end{array}$ & $\begin{array}{l}\text { Length of } \\
\text { parietal }\end{array}$ & $\begin{array}{l}\text { Width of } \\
\text { parietals }\end{array}$ & $\begin{array}{l}\text { Length of } \\
\text { frontal }\end{array}$ & $\begin{array}{l}\text { Length of } \\
\text { nasal }\end{array}$ & $\begin{array}{l}\text { Width of } \\
\text { nasal }\end{array}$ & $\begin{array}{c}\text { V8 } \\
\text { Connecting } \\
\text { line of } \\
\text { lateral tips } \\
\text { of } \\
\text { prefrontals }\end{array}$ \\
\hline D107 & 55 & 8.5 & 25.5 & 9.0 & 16.5 & 11.5 & 7.5 & 4.5 & 17.5 \\
\hline K323 & 56 & 14.0 & 39.0 & 13.0 & 23.5 & 17.0 & 12.0 & 7.0 & 28.0 \\
\hline K325 & 57 & 10.0 & 25.5 & 10.0 & 14.5 & 13.0 & 7.5 & 4.5 & 16.0 \\
\hline K $329 . I$ & 58 & 6.5 & 23.0 & 6.5 & 13.0 & 6.5 & 4.0 & 4.0 & 13.0 \\
\hline K340.I & 59 & 9.0 & 29.0 & 9.5 & 18.0 & 11.0 & 7.0 & 5.5 & 21.0 \\
\hline K330 & 60 & 10.0 & 29.0 & 11.0 & 17.0 & 10.0 & 6.5 & 5.0 & 18.5 \\
\hline K331. I & 61 & 9.5 & 21.5 & 9.5 & 14.0 & 12.0 & 5.5 & 4.5 & 16.5 \\
\hline K331.II & 62 & 9.0 & 25.5 & 8.0 & 16.0 & 11.5 & 8.0 & 4.5 & 18.0 \\
\hline K 326 & 63 & 8.5 & 28.0 & 9.0 & 16.5 & 13.0 & 8.5 & 4.5 & 18.5 \\
\hline D354.I & 64 & 9.5 & 24.0 & 10.0 & 14.0 & 11.0 & 7.5 & 4.5 & 15.5 \\
\hline K344 & 65 & 7.0 & 23.5 & 7.5 & 13.5 & 9.5 & 6.5 & 3.5 & 16.0 \\
\hline K345 & 66 & 10.0 & 20.5 & 9.5 & 16.0 & 13.0 & 8.0 & 4.5 & 18.5 \\
\hline K342 & 67 & 7.0 & 20.0 & 7.5 & 12.5 & 9.5 & 4.5 & 3.5 & 13.5 \\
\hline K334 & 68 & 10.0 & 26.0 & 9.5 & 16.5 & 12.0 & 7.0 & 5.0 & 18.5 \\
\hline K335 & 69 & 8.5 & 22.5 & 9.5 & 15.0 & 10.5 & 9.0 & 5.0 & 16.0 \\
\hline K347 & 70 & 8.0 & 22.5 & 8.5 & 14.0 & 8.5 & 4.5 & 3.5 & 14.0 \\
\hline
\end{tabular}

*Interorbital width is measured at level of contact of prefrontal with postfrontal.

tThis connecting line is measured from level at which interorbital width was measured.

$\ddagger$ Orbit is measured from its anterior margin.

$\S$ Connecting line between posteromedial and posterolateral tips of squamosal.

Analysis of within-group variation. The pattern of character variation within a measured group of Discosauriscus specimens is described using principal component analysis. Because the principal component analysis (PCA) with the correlation matrix of $\log _{\mathrm{e}}$-transformed data tends to incorporate less shape into the first component (PCl) than PCA with covariance matrix (Sommers, 1986), we applied the correlation matrix in the analysis of within-group variation (Jolicoeur, 1963a).

Principal components (PCs) are linear combinations of the measured original variables, and so their orientations are defined by the vectors of coefficients (eigenvectors) in those combinations. PC2 describes the largest shape variance. Other components follow similarly but in other directions of data variation than PC2. Closely related is the problem of how many PCs should be interpreted. We think that the procedure does not depend on a file of limiting assumptions and we try to explain 95\% of data variance (cf. Jolicoeur, 1963a). Because the PCl could be considered as a growth trend (cf. Jolicoeur, 1963b) we use it to analyse the trends in the development of measured animals.

Ontogenetic analysis. For this purpose we used the PCl but from a covariance matrix (Jolicoeur, 1963b,c) of $\log _{\mathrm{e}}$-transformed data. Our preference for the lognormal model is based on the reasons described by Mosimann \& James (1979). The eigenvector (PC1) exctracted from such a covariance matrix describes relative changes in the measured characters during growth (Strauss, 1985) and partially characterize the ontogenetic level of the examined animals (Jolicoeur, 1984), for example, if the proportions of an $i$ th variate to a $j$ th variate were to remain constant as the size of a living organism increases, that is, if the 
continued

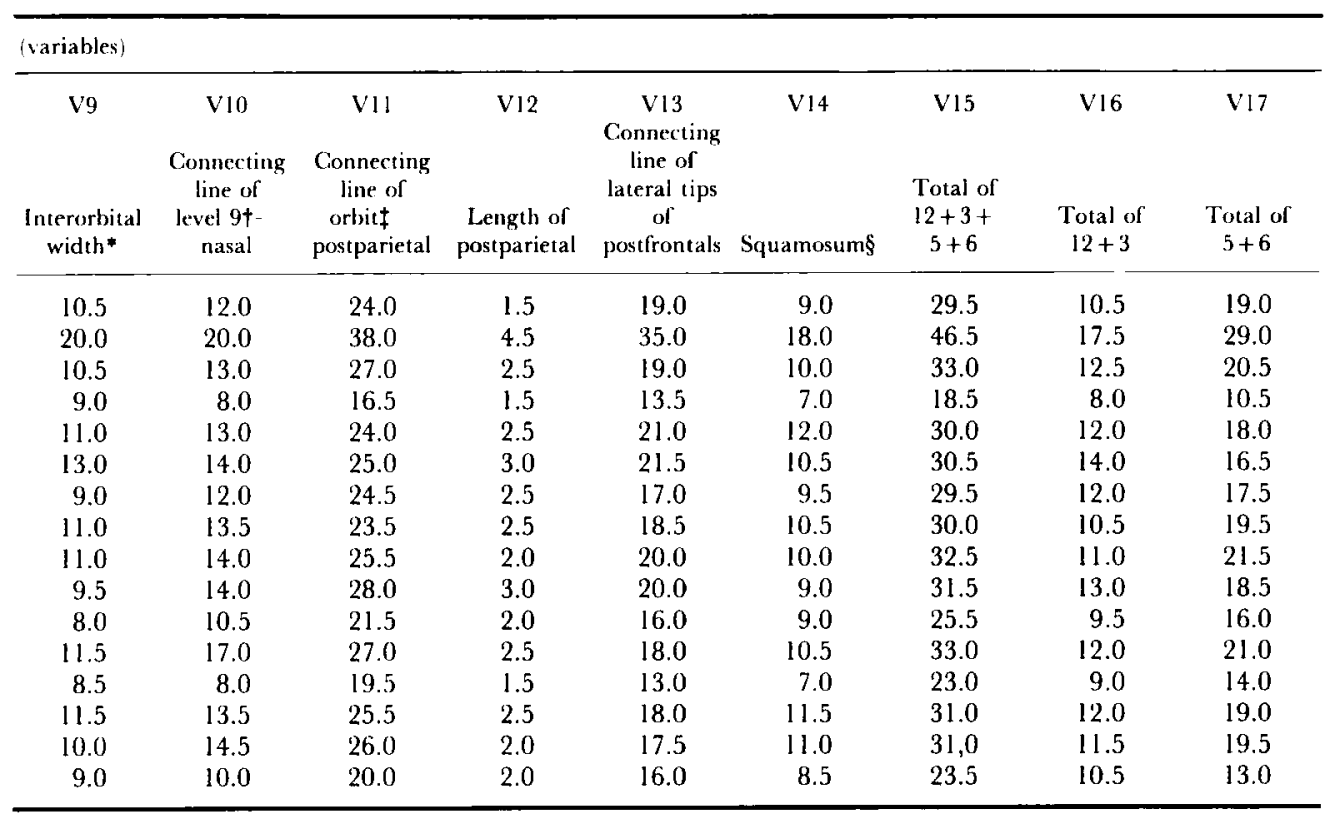

relative growth of the two dimensions were isometric. In our case the hypothesis that the $i$ th variate is isometric could thus be expressed as: eigenvector $=$ $1 / \operatorname{sqr}(17)=0.2425356$, because we used 17 variables.

Analysis of between-group variation. To examine a between-group separation we applied discriminant analysis (Jolicoeur, 1959). From the scatter of the PC2 and PC3 of the correlation matrix we identified the structure associated with the shape differences among groups with the help of cluster analysis (Humphries $e t$ $a l ., 1981$ ). In palaeobiological data we did not suggest the existence of groups $a$ priori; hence we used the hierarchial ordination (Euclidean matrix, maximum distance method-see Šarmanová \& Lukasová, 1985). To determine a parallel between PCA and discriminant analysis we computed ten clusters (the first ten components accounted for approximately $95 \%$ of the data variation in the PCA). For these ten groups we computed the standardized loadings and discriminant scores from the data matrix of the first 14 measured variables (Table 1). Because the shape components from PCA are the types of discriminators we compared them to the usual linear discriminant function (Humphries et al., 1981).

\section{STATISTICAL ANALYSES: RESLLTS}

Taxonomic notes and skull proportions

Špinar (1952) has at his disposal an extensive collection of different ontogenetic stages of discosauriscids, from several localities of the Boskovice 
Furrow. The specimens were found on the bedding plane surfaces, dorsoventrally compressed and often distorted. Using this material, Špinar distinguished two genera and four species: Discosauriscus pulcherrimus, D. potamites, Letoverpeton moravicum and L. austriacum. The diagnoses of both genera (Špinar, 1952: 23 for Discosauriscus, Špinar, 1952: 59 for Letoverpeton) are based entirely on differences in proportions. Discosauriscus has a narrow and elongated skull and is more gracile. Furthermore, the individual bones of the skull are narrower and longer. Postcranially, the interclavicle is long and the ischium is narrow and posteriorly elongated; the body length reaches $350 \mathrm{~mm}$. Letoverpeton has a broader, shorter and more robust skull. The skull bones are relatively shorter and broader (the parietal is never broader than long). Postcranially, the interclavicle is short and stout and the ischium is broad and triangular; body length is c. $250 \mathrm{~mm}$.

The orbit of Discosauriscus has the shape of an irregular oval whereas in Letoverpeton it is broad with a longer posterolateral axis. From Špinar's diagnoses, it follows that there are no morphological differences apart from proportional ones.

Considering the diagnoses of the four species (Š pinar, 1952: 28, 50-52, 61, 7374 ), the differences between them are also only proportional and the value of other characters is problematic.

(1) These characters are common for both genera and have no taxonomic value (e.g. width of interpterygoid vacuities, presence of the small laterocaudal processes of the parietal, junction of the parietal with the tabular, number of digits per limb, phalangeal formula, number of type of bones of the pectoral and pelvic girdles, shape of scales, etc.).

(2) Because of a considerable degree of dorsoventral compression it is impossible to regard proportional characters as unambiguously diagnostic, and it is necessary to be very careful (e.g. degree of vaulting of the squamosal, shape of orbit, etc); this throws doubt on the possibility of exact measuring.

(3) It is impossible to compare them in all four species because of imperfect preservation (e.g. number of caudal ribs, number of caudal vertebrae). Apart from proportional differences (e.g. 'narrow' vs 'broad' skulls), which, however, can now be reinterpreted (see below), it is impossible to determine unambiguous morphological differences between individual species.

In his redescription of the German discosauriscids, Werneburg (1985, 1989) accepted the existence of three of Spinar's species although he cast doubt upon the existence of $D$. potamites, which he considered to be synonymous with $D$. aff . pulcherrimus-cf. Werneburg (1989: 34). Werneburg denoted, as D. pulcherrimus, the type material from Ruprechtice (North Bohemia) and two German localities (Niederhässlich and Wintersbrunnen). On the palate of the specimens from Niederhässlich, he described two basic characters: the sharply triangular denticle field on the parasphenoid and only one pair of tusks on the vomers. According to Werneburg (1989), these characters have not been demonstrated on the specimens from the Boskovice Furrow, and therefore he identified them as $D$. aff. pulcherrimus. However, Werneburg's statements are not correct for the following reasons: (1) in the majority of well-preserved specimens from the Boskovice Furrow, the lateral margin of the vomer is bordered by a row (one or more) of small denticles and medially from it three pits for tusks are situated in one line (mostly two tusks are present), e.g. in $\mathrm{K} 83$; (2) on the ventral side of the 
parasphenoid of K 9 and K 323 (but known only in these two specimens) the triangular denticle field is present.

Apart from the differences between Discosauriscus and Leloverpeton, Werneburg $(1985,1989)$ on the basis of the length, width, massiveness, gracility and size of individual bones, the shape of orbit or proportions of some parts of the skull also presented other differences between these genera. These include the structure and form of the parasphenoid, vomer, mandible, interclavicle, ischium and the number of vertebrae. The new material of Discosauriscus from the Boskovice Furrow, however, permits us to present preliminary statements (a detailed description of the skeleton and complete documentation will be given in later papers) about all of these characters.

Parasphenoid. The shape of the parasphenoid is identical in 'narrow' (e.g. D 73) and 'broad' (e.g. D 100) skulls, i.e. in both marginal cases the parasphenoid has a long posterolateral processes, reaching up to the region of quadrate (they probably covered from the ventral side the posterolaterally-widened endocranial 'otic tubes'). The type of parasphenoid which Werneburg (1989: Fig. 12) illustrated for Discosauriscus has never been found in our material. The posterolateral processes of the parasphenoid are fragile, which is why they are often broken, or 'pressed' to the ventral wall of the skull roof.

Vomerine dentition. According to Werneburg (1989: 35, Fig. 12), Letoverpeton austriacum differs from $L$. thuringiacum in the absence of the tusks. Here it must be emphasized that the vomerine dentition is the same in both 'narrow' (e.g. D 73) and 'broad' (e.g. K 14, K 339) skulls. In these specimens the lateral margin of the vomer is bordered by a row of denticles (sometimes they are more abundant, or the denticles form clusters, mostly in the anterior part) and closely medially from it three tusk positions are visible (see above).

Mandible. In the mandible, it has proved impossible to determine unambiguously the boundary between the 'large coronoid and small surangulare' in Discosauriscus and the 'small coronoid and large surangulare' in Letoverpeton (Werneburg, 1985: Table 3).

Interclavicle. In the interclavicles, there are proportional differences as in the skulls, especially in the comparison of the specimens with the 'narrowest' and the 'broadest' skulls. As Špinar (1952) found, the former are longer and more gracile specimens, the latter are shorter, more plump and more robust. Werneburg (1985: Table 3) suggested that the interclavicle in Discosauriscus has a relatively narrower stem and longer and narrower anterior plate, whereas in Letoverpeton there is the opposite situation. Figure 3 shows that in the specimen with the 'broad' skull ( $\mathrm{K} 339$ ), the anterior half of the posterior stem is only slightly broader when compared with 'narrow' skull of the specimen K 337 . However, it is not the case that the posterior stem in specimens with 'narrow' skulls is longer than in specimens with 'broad' skulls. The posterior stem of the interclavicle of D 100 (broad skull) is substantially longer than that of D 106 (narrow skull); both specimens are of almost equal size. In the anterior plate of the interclavicle, the 'differences' are ambiguous. In 'Letoverpeton' specimens with 'broad' skulls (e.g. K 346.I), the anterior plate is not always shorter and broader in comparison with the interclavicles of Discosauriscus (Fig. 2, and Werneburg, 1985: fig. 8 and pl. 6, figs 1-5; Špinar, 1952: pl. 33).

Ischium. Werneburg (1985: Table 3) argued that the ischium of Letoverpeton was broad with a short posterior laterocaudal corner, unlike the long, narrow 


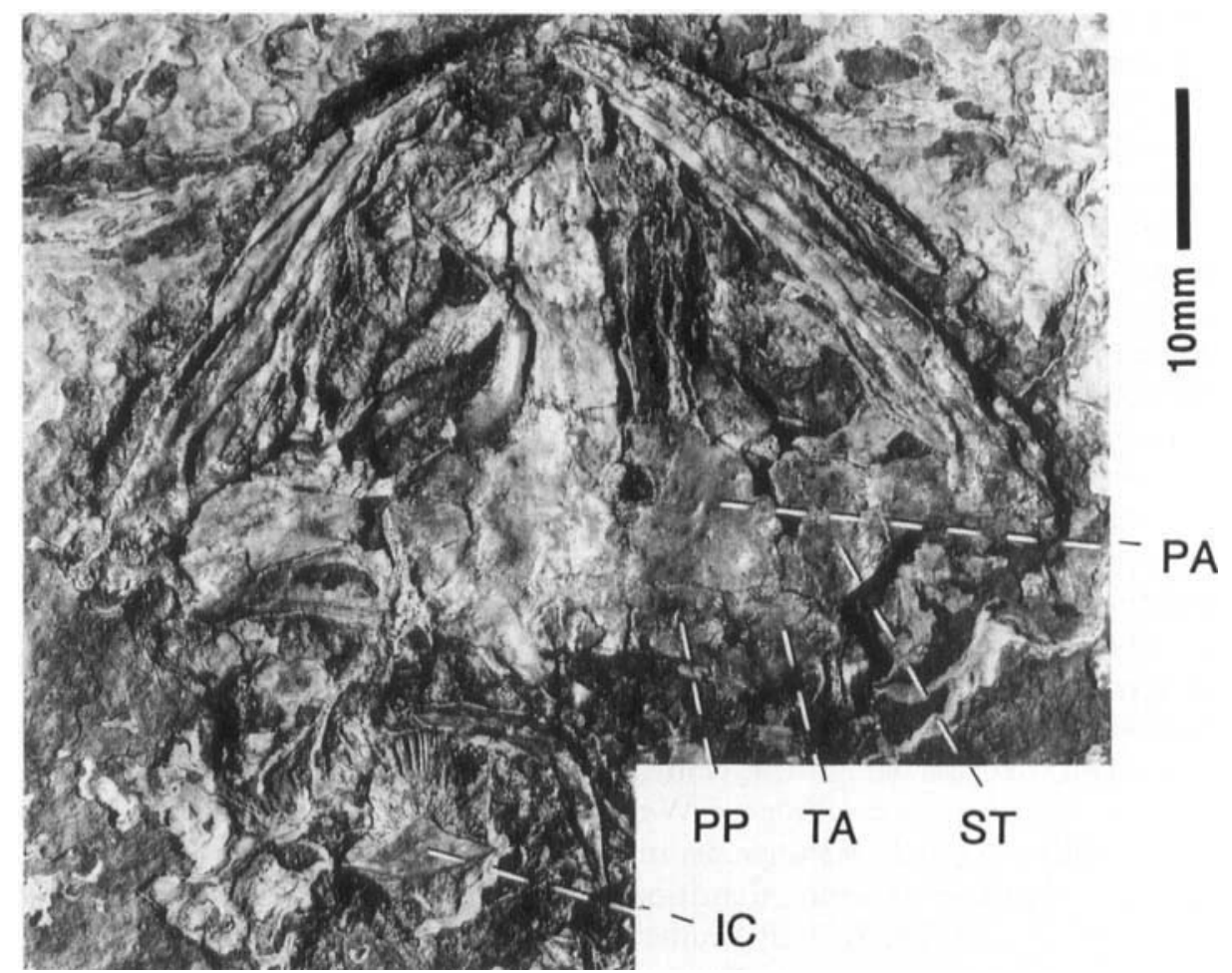

Figure 2. Discosauriscus austriacus (Makowsky, 1876), K 346.I. Skull in ventral aspect and disarticulated shoulder girdle. (For key to abbreviations see p. 270.)

ischium with a long laterocaudal corner in Discosauriscus. The ischium in the specimens with 'narrow' skulls is indeed narrower; however, this shape of ischium and its caudal corner, as illustrated by Werneburg (1985: Fig. 10n-Letoverpeton austriacum) has not been found in the new material. In a specimen with a 'broad' skull (K 341.I), which corresponds to the species L. austriacum (Fig. 4), the shape and posterior ending of the ischium is virtually identical to the specimens with the 'narrow' skulls (e.g. K 328).

Vertebrae. Unfortunately no specimen with an explicitly 'narrow' skull was found in which the number of the presacral vertebrae could be unambiguously determined. In $\mathrm{K} 347$, the skull of which corresponds to the transition between D. pulcherrimus and L. austriacum, there are 24 presacral vertebrae, as in the 'broad' skulls (e.g. K 323, K 338.I).

\section{Within-group variation}

The nature and importance of the trend of variation corresponding to each $\mathrm{PC}$ can be judged from the signs and the numerical values of its eigenvectors (Table 2) and from the amounts of variance associated with each component (Table 3). PG 1 was a strong size vector, accounting for more than $64 \%$ of the variance. It has consistently positive loadings and because it also represents the general growth trend we discuss it below under 'Growth allometry'.

PC 2 is also substantial, accounting for more than $9 \%$ of variation. This 

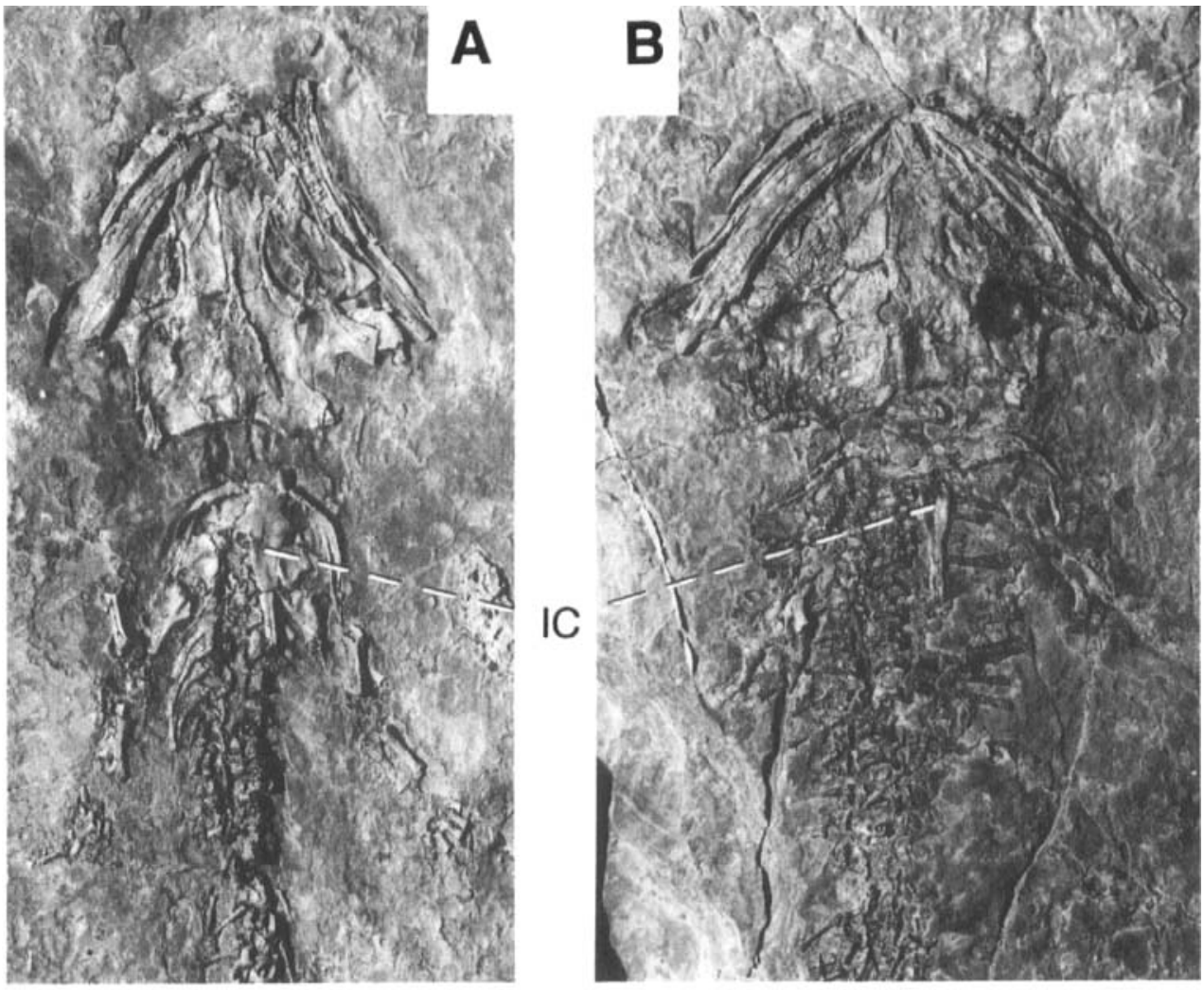

Figure 3. Discosauriscus austriacus (Makowsky, 1876). A, K 337; B, K 339. Skulls and parts of postcranial skeletons of two proportionally different specimens in ventral aspects. Scale bars = $10 \mathrm{~mm}$.

component refers to the contrast between the width and length of the skull and represents the trend which connects with the present understanding of the importance of the proportional differences within Discosauriscus specimens. The length-width contrast is not even; the greater increase in the width of the posterior part of skull (V2 and V4) is reflected in the length (V5).

Also the next shape trend obtained by PCA was discussed in the literature (Berman, Reisz \& Eberth, 1987) on the example of the length of the postparietal in Seymouria (see below). PC 3 represents an almost unipolar shape trend of elongation or shortening of skull in the region of the parietal (V3), especially in the region of the postparietal (V12). In other words, there are specimens with lengthened postparietals as well as others with proportionately short postparietals. The data in Table 2 show a significant independence between this and preceding length-width trend. The trend (PC 3) refers rather to the contrast between the length of the anterior and posterior parts of skull. The skulls with proportionally long postparietals have partly proportionally shortened nasals (V6).

The next trend (PC 4) is the shortening or elongation of the postparietal, but this time in contrast with the length of the adjoining bone - the parietal. As Jolicoeur \& Mosimann (1960) stated, a positive deviation of 100 units in this 


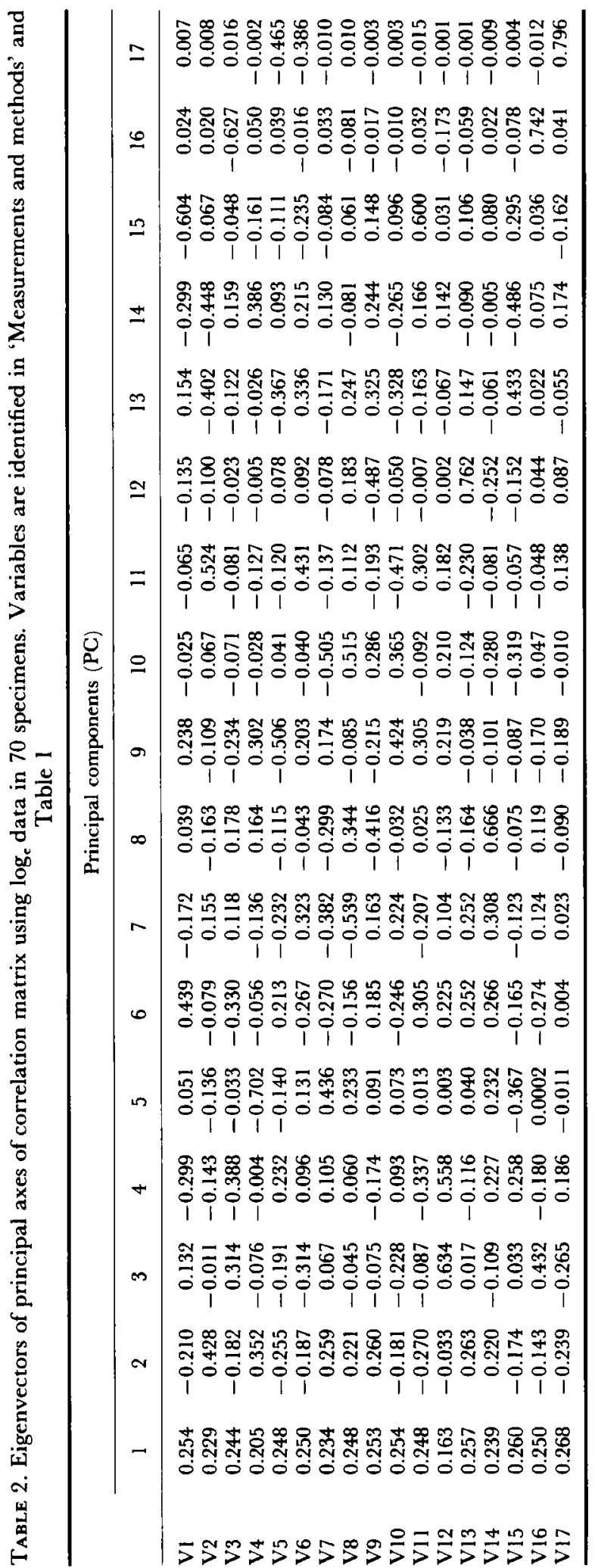




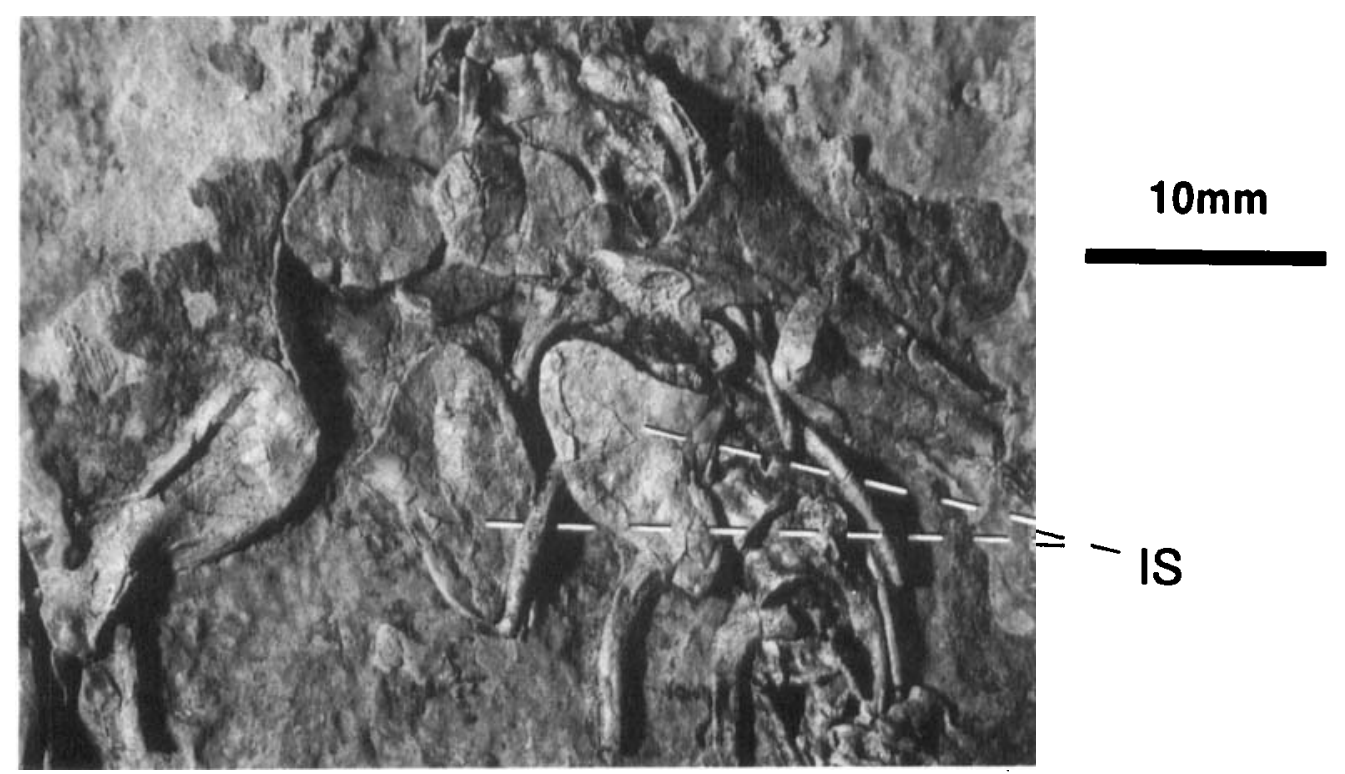

Figure 4. Discosauriscus austriacus (Makowsky, 1876), K 341.I. Pelvic girdle.

trend of shape would correspond to deviation of $+55 \mathrm{~mm}$ in the postparietal length and $-39 \mathrm{~mm}$ in the parietal length or vice versa.

It is interesting that the posterior part of the skull is mainly 'responsible' for the distinct shape variability of the skull in Discosauriscus. PC 5 also relates to the shape variability of the posterior part of the skull, in this case with the width of the parietals (V4). It is an almost unipolar vector which provides information on the proportional decrease of the width of parietals in some specimens, whereas the other specimens have the width of nasals (V7) proportionally greater in comparison with other bones of skull.

TABle 3. Eigenvalues and percentage variance accounted by each principal component (correlation matrix)

\begin{tabular}{ccc}
\hline PC & Eigenvalues & Percent of variance \\
\hline 1 & 11.01 & 64.8 \\
2 & 1.59 & 9.4 \\
3 & 1.09 & 6.4 \\
4 & 0.66 & 3.9 \\
5 & 0.56 & 3.3 \\
6 & 0.42 & 2.5 \\
7 & 0.33 & 2.0 \\
8 & 0.29 & 1.7 \\
9 & 0.27 & 1.6 \\
10 & 0.20 & 1.2 \\
11 & 0.17 & 1.0 \\
12 & 0.13 & 0.8 \\
13 & 0.12 & 0.7 \\
14 & 0.08 & 0.4 \\
15 & 0.06 & 0.3 \\
16 & 0.01 & 0.0 \\
17 & 0.00 & 0.0 \\
\hline
\end{tabular}


TABLE 4. Eigenvectors of first four principal axes of covariance matrix using $\log _{c}$ data in 70 specimens. Variables are identified in 'Measurements and methods' and 'Table 1

\begin{tabular}{lrrrr}
\hline & \multicolumn{4}{c}{ Principal components } \\
\cline { 2 - 5 } & 1 & \multicolumn{1}{c}{ 2 } & \multicolumn{1}{c}{3} \\
\hline V1 & 0.237 & 0.011 & -0.179 & \multicolumn{1}{c}{-0.362} \\
V2 & 0.193 & 0.015 & 0.385 & -0.089 \\
V3 & 0.220 & 0.067 & -0.160 & -0.459 \\
V4 & 0.194 & -0.007 & 0.370 & -0.030 \\
V5 & 0.226 & -0.115 & -0.202 & 0.153 \\
V6 & 0.315 & -0.324 & -0.202 & 0.324 \\
V7 & 0.206 & 0.066 & 0.227 & 0.052 \\
V8 & 0.229 & -0.012 & 0.226 & 0.042 \\
V9 & 0.251 & -0.049 & 0.302 & -0.123 \\
V10 & 0.274 & -0.204 & -0.169 & 0.204 \\
V11 & 0.262 & -0.175 & -0.250 & -0.343 \\
V12 & 0.245 & 0.850 & -0.197 & 0.283 \\
V13 & 0.267 & 0.028 & 0.310 & -0.122 \\
V14 & 0.252 & -0.010 & 0.264 & 0.284 \\
V15 & 0.243 & 0.024 & -0.161 & 0.108 \\
V16 & 0.223 & 0.192 & -0.146 & 0.328 \\
V17 & 0.257 & -0.192 & -0.199 & 0.219 \\
\hline
\end{tabular}

PC 6 also corresponds with variation in the bones of the posterior part of skull. The variation is expressed especially by the complementary changes in the length of the parietal foramen-postparietal (V1) and parietal (V3). When V3 proportionally increases in relation to the total size of skull, Vl decreases, and vice versa.

PC 7 is the first trend, which 'represents' the greater width-length changes in the anterior part of skull, mainly in the region of the nasal. It is interesting that this trend, in comparison with the preceding ones, partially correlates with size (correlation between $\mathrm{PC} 1$ and $\mathrm{PC} 7=0.3$ ).

PC 8 (always $c .2 \%$ of the total data variance) corresponds to the variation in the width of the squamosal (V14).

Other trends in the shape of Discosauriscus skulls are given in Table 2. Although a lower percentage of the total data variability, in terms of phylogeny (cf. Jolicoeur, 1963a) they may be important and they are therefore given here (see Table 2) in full.

\section{Growth allometry}

Because the discosauriscids were probably neotenic animals (Holmes, 1984; Smithson, 1985), it is necessary to define the stages of their ontogenetic development for better determination of the shape variability of the skull.

PC 1 corresponds to a direction of size increase and can therefore be interpreted as a growth trend. Use of the covariance matrix preserves allometries (Tables 4, 5). In our case, the very divergent variable in the shape - the length of postparietal (V12) - grows isometrically, like the total skull length (V15), but both are positively allometric to the widths of V4 or V2. The nasal length $(0.31)$ is also positively allometric to the nasal width. PC 1 corresponds to the overall 
TABle 5. Percent of variance accounted for by each PC using covariance matrix

\begin{tabular}{cc}
\hline $\mathrm{PC}$ & Percent of variance \\
\hline 1 & 63.03 \\
2 & 9.79 \\
3 & 8.51 \\
4 & 4.08 \\
5 & 2.94 \\
6 & 2.35 \\
7 & 1.84 \\
8 & 1.69 \\
9 & 1.49 \\
10 & 1.14 \\
11 & 1.09 \\
12 & 0.79 \\
13 & 0.62 \\
14 & 0.38 \\
15 & 0.31 \\
16 & 0.04 \\
17 & 0.03 \\
\hline
\end{tabular}

tendency, that the length of skull increases (during growth) at a greater relative rate than the skull width.

\section{Between-group variation}

To each variance component in the discriminant analysis correspond 14 standardized canonical discriminant function coefficients; the numerical values of the first four coefficients are given in Table 6. More than 95\% of betweengroup variance was accounted for by the first three functions (Table 7).

The pattern of dispersion of the groups in the plane of the first and second discriminant axes is shown in Fig. 5. Group 9 tends to congregate in the left side of the graph.

As the data in the Tables 6 and 8 show, the proportional changes in the length of the postparietal (and partially in the length of nasal, but in contrast to the

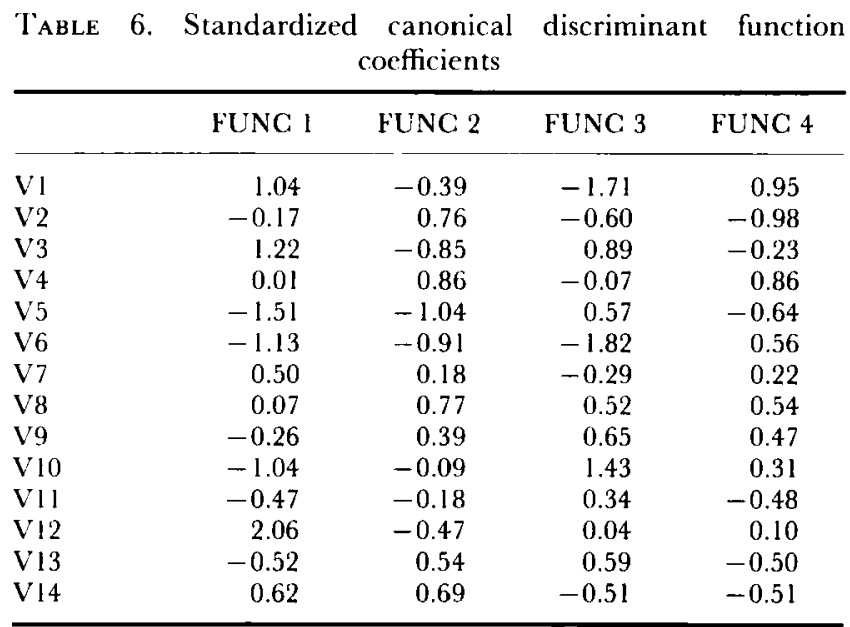


TABLE 7. Multiple discriminant analysis

\begin{tabular}{lccccc}
\hline $\begin{array}{l}\text { Discriminent } \\
\text { function }\end{array}$ & Eigenvalues & $\begin{array}{c}\text { Relative } \\
\text { percentage }\end{array}$ & \multicolumn{1}{c}{$\chi^{2}$} & dF & $\begin{array}{c}\text { Significance } \\
\text { level }\end{array}$ \\
\hline 1 & 13.34 & 56.61 & 370.77 & 126 & 0.00 \\
2 & 8.15 & 34.60 & 218.98 & 104 & 0.00 \\
3 & 0.99 & 4.20 & 92.80 & 84 & 0.24 \\
4 & 0.51 & 2.18 & 53.61 & 66 & 0.86 \\
5 & 0.26 & 1.11 & 30.02 & 50 & 0.99 \\
6 & 0.12 & 0.51 & 16.76 & 36 & 0.997 \\
7 & 0.11 & 0.45 & 10.29 & 24 & 0.99 \\
8 & 0.06 & 0.25 & 4.59 & 14 & 0.99 \\
9 & 0.02 & 0.10 & 1.28 & 6 & 0.97 \\
\hline
\end{tabular}

postparietal) are the most distinct differentiating characters between groups. The first component is markedly larger $(57 \%$ ) than the next (proportional variability in the length and width of skull) and except for group 9 the variability in the length of the postparietal also separates groups $2,3,5,6,7$, and 8. The 'length-width' trend differs mainly between group 1 and groups 10 and 4 (Fig. 5A, Table 8). We compared the first function discriminant scores and the component scores from the PC analyses (PC 2-covariance matrix and PC 3 -correlation matrix) and, as can be seen in Figs $5 B, C, D_{1}$ achieves some discrimination between two possible groups. One group (shorter postparietal) comprises the animals from groups $9,10,5,3$ and 7 ; in the second group are the specimens from other groups. Level $D_{1}$, in which the specimens can be differentiated, has an approximate value 0 . It can be seen from the frequency histogram (Fig. 5D), that after division of 70 specimens into 30 groups (according to the value of discriminant scores), the group on level 0 is absent. The relation between the postparietal length (V12) and the frontal length (V5) could represent a certain distinguishing but unsteady criterion in this point 0 of $\mathrm{D}_{1}$, because they mostly vary in the discriminant function 1 , and a decrease in the frontal length is accompanied by an increase in the postparietal length. For the reasons given below, however, it is impossible to consider such separation as a valuable taxonomic criterion. It is still more doubtful in the other trends $\left(D_{2}\right.$, $\mathrm{D}_{3}, \mathrm{D}_{4}$-Table 6 , Fig. $5 \mathrm{~A}$ ), in which values of the discriminant scores coincide much more (Fig. 6).

TABLE 8. Group centroids of first two discriminant functions. Numbers of groups correspond to those in Fig. 5A-C.

\begin{tabular}{lrr}
\hline & FUNC 1 & FUNC 2 \\
\hline Group 1 & 1.03 & -3.77 \\
Group 2 & 1.47 & -0.57 \\
Group 3 & -1.89 & -0.72 \\
Group 4 & 1.85 & 4.22 \\
Group 5 & -4.14 & -3.46 \\
Group 6 & 4.26 & 1.55 \\
Group 7 & -2.15 & 0.86 \\
Group 8 & 5.00 & -1.67 \\
Group 9 & -7.73 & 0.70 \\
Group 10 & -3.98 & 5.49 \\
\hline
\end{tabular}



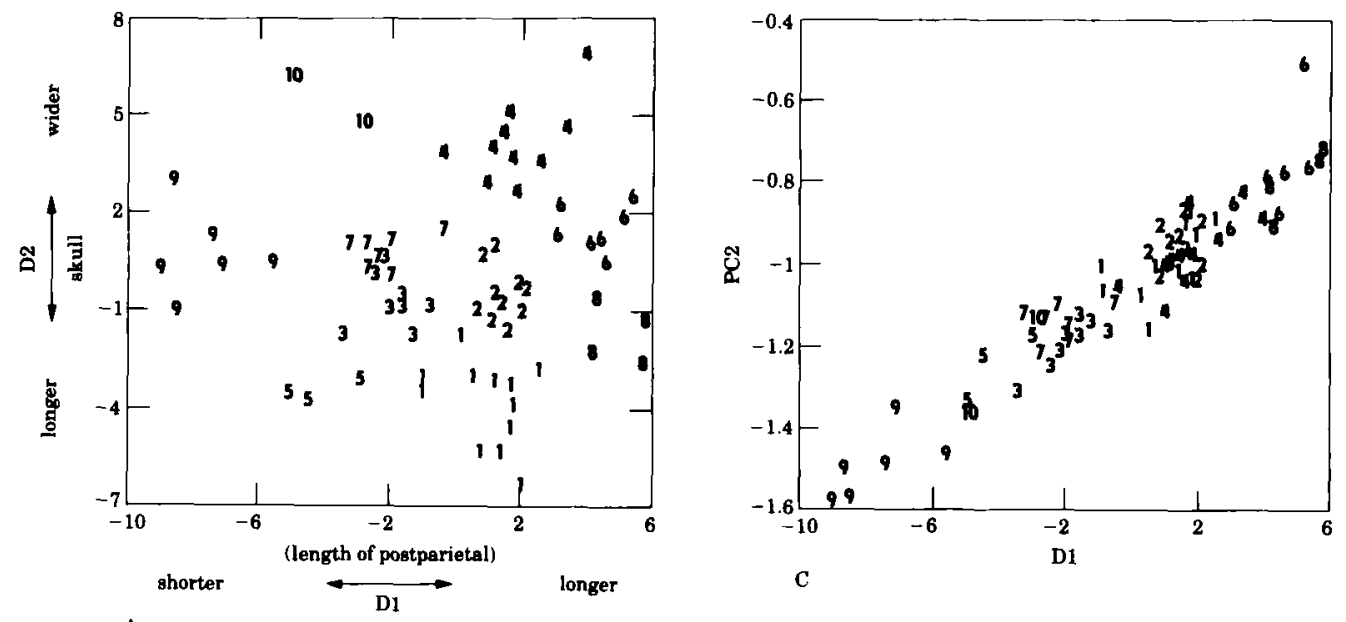

A
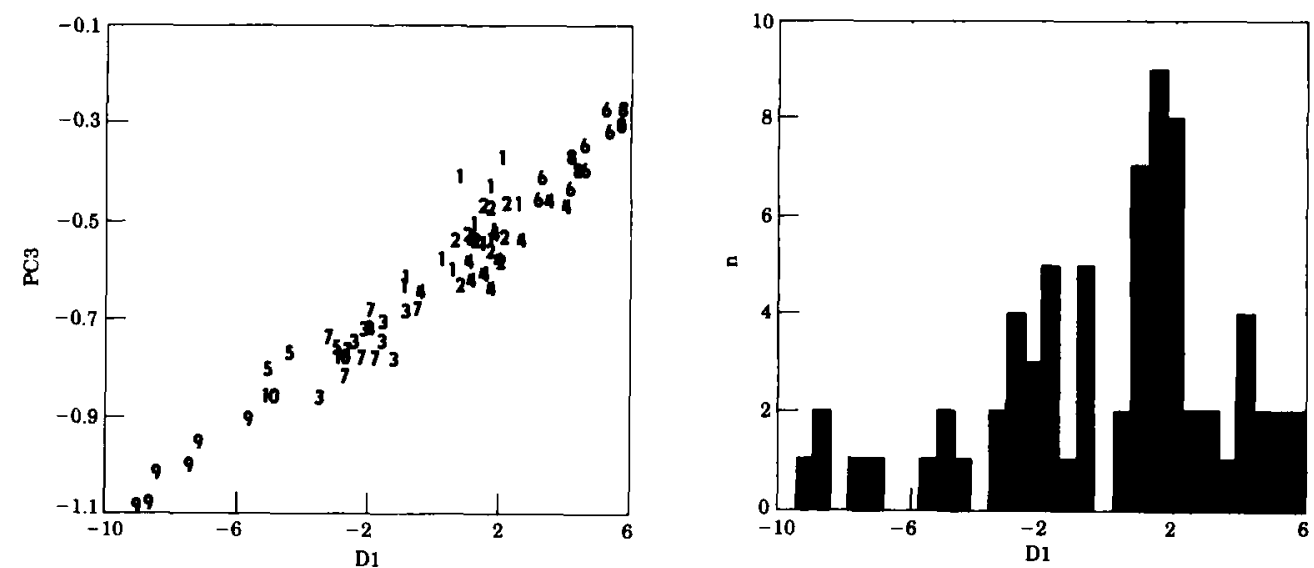

Figure $5 \mathrm{~A}-\mathrm{D}$. A, Scatter of scores computed from first $\left(\mathrm{D}_{1}\right)$ and second $\left(\mathrm{D}_{2}\right)$ discriminator (see also Tables 2-8). Numbers of groups are derived from hierarchial cluster analysis. B, Principal component 3 (derived from correlation matrix) and C, PC 2 (from covariance matrix) scattered against the first discriminator $\left(D_{1}\right)$. D, Frequency histogram derived from the scores of the first discriminator $\left(D_{1}\right)$ divided into 30 frequency groups $(n=$ Number of specimens).

\section{DISCUSSION}

The statistical analysis indicates that in this assemblage of Discosauriscus specimens there are several trends in variability of skull shape, as in the populations of other animals. As the independent shape trends in PCA show, it is impossible to divide this material into narrow and long ('Discosauriscus') or broad and short ('Letoverpeton') skulls, i.e. that all length characters would proportionally equally lengthen, and broad characters would equally shorten or vice versa, as understood hitherto (Špinar, 1952; Werneburg, 1985, 1989; see above). Multivariate PCA shows that the relationships between the proportions of individual bones are more complicated, although it is possible to find specimens in these collections which are notably proportionally different in a given region of the skull (e.g. the skull table, Fig. 8). Specimen K 58 (Fig. 8B) is one in which the parietal is broader than it is long. It is evident that, for 


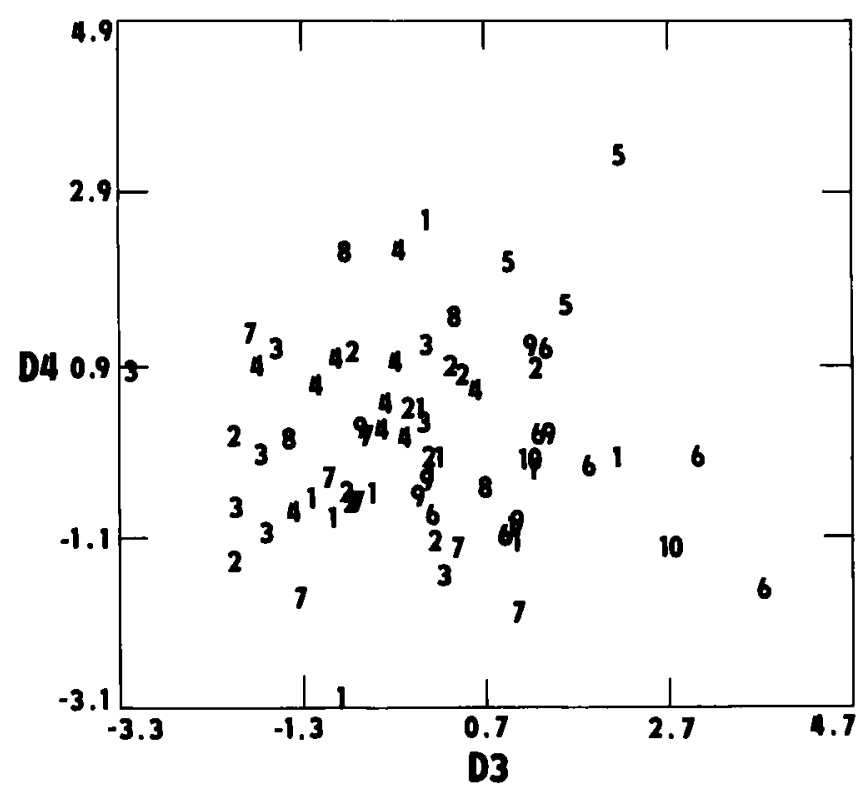

Figure 6. Scores of the fourth discriminator $\left(D_{4}\right)$ scattered against the scores of the third discriminator $\left(D_{3}\right)$. For more detailed explanation of the shape variation see Table 6 .

example, a particular proportionally narrow bone can be on both 'broad' and 'narrow' skulls (this also follows from PCA). The division of the specimens into 'narrow' and 'broad', on the basis of skull proportions, is incorrect. We follow Jolicoeur (1959), who applied discriminant analysis to the shape variability in the skull of Recent populations of Canis lupus. Although studying a very different group of animals, the author found significant length-width variability in the shape of the skull, which correlated significantly with occurrence in different geographical regions. Theoretically it means that although it may be possible to distinguish (on the basis of measurements of the shape changes of bones) several groups from the characteristics obtained (using the component scores, some groups of wolves did not overlap in Jolicoeur's graphs), within the Moravian discosauriscids, this also does not imply the existence of two or more species.

The only trend which markedly differentiates the analysed collection of specimens is the variability in the length of the postparietal and, in part, the nasal. However, in the specimens with the short postparietal (Fig. 5A, group 9), this bone elongates significantly laterally from the median plane (where it was measured), similar to the parietal, frontal and nasal. The difference can be up to $1 \mathrm{~mm}$, in contrast to other specimens, in which this difference is almost zero (Fig. 9). These shape differences in the postparietal also influenced the results of discriminant analysis.

The only character on which Vaughn (1966) differentiated the new species Seymouria sanjuanensis from Broili's (1904) species S. baylorensis (cf. White, 1939), was the greater anteroposterior length of the postparietal and tabular in the former. Vaughn (1966) had only two specimens of S. sanjuanensis for measurement of these bones. Berman, Reisz \& Eberth (1987) confirmed Vaughn's differentiating character for these two species and demonstrated other characters. These authors measured the length of the postparietal on three 


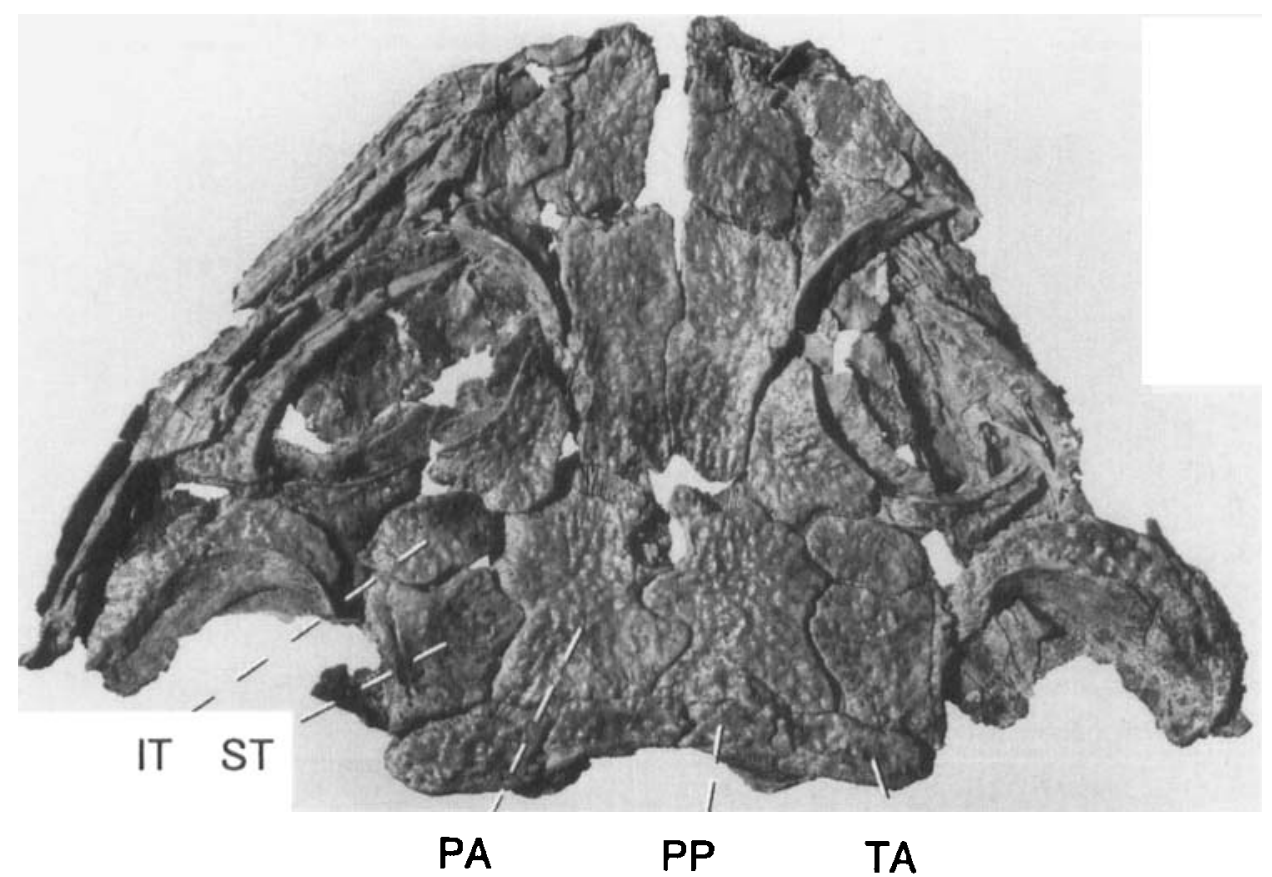

Figurc 7. Discosauriscus austriacus (Makowsky, 1876), K 20. Skull in dorsal view. Scale bar $=10 \mathrm{~mm}$. (For key to abbreviations see p. 270.)

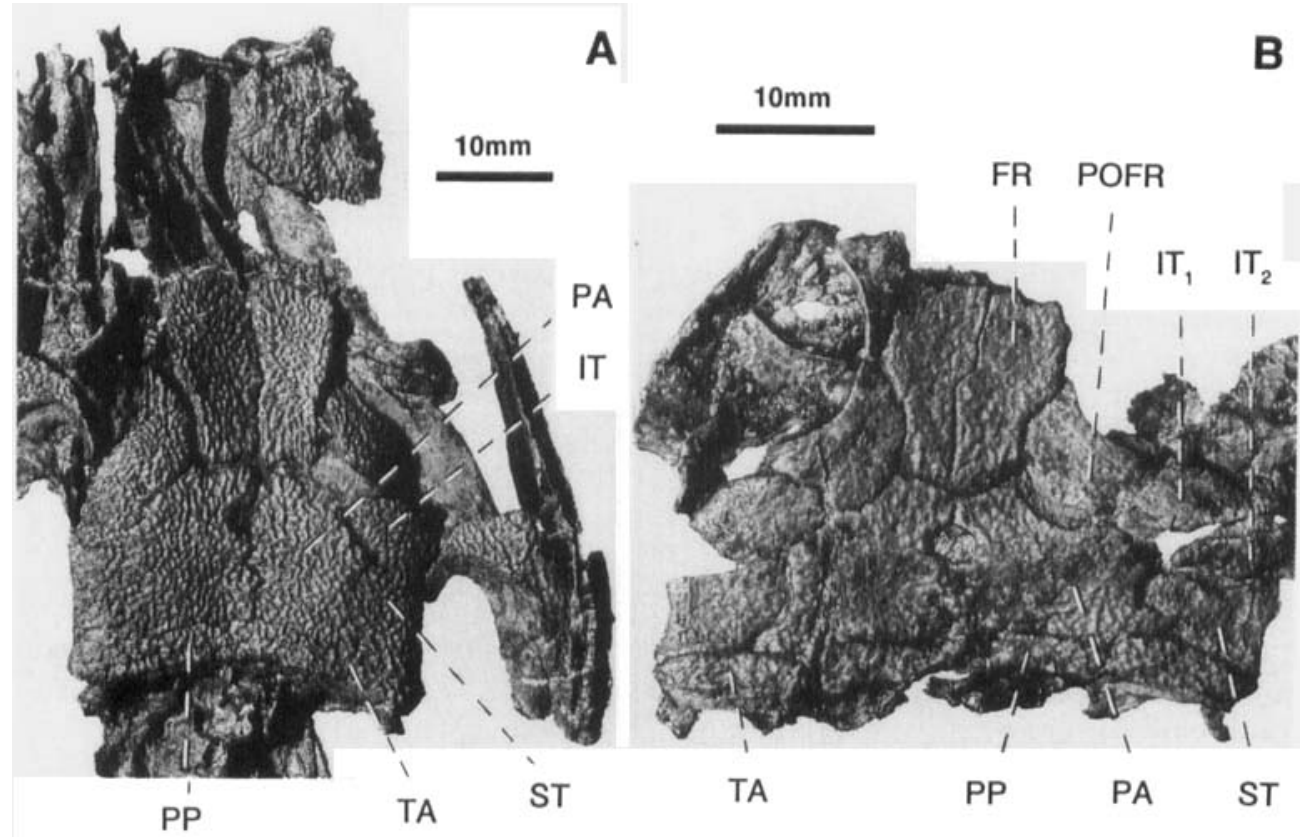

Figure 8. Discosauriscus austriacus (Makowsky, 1876). A, K 16; B, K 58. Skulls of two proportionally different specimens in dorsal aspect. (For key to abbreviations see p. 270.) 


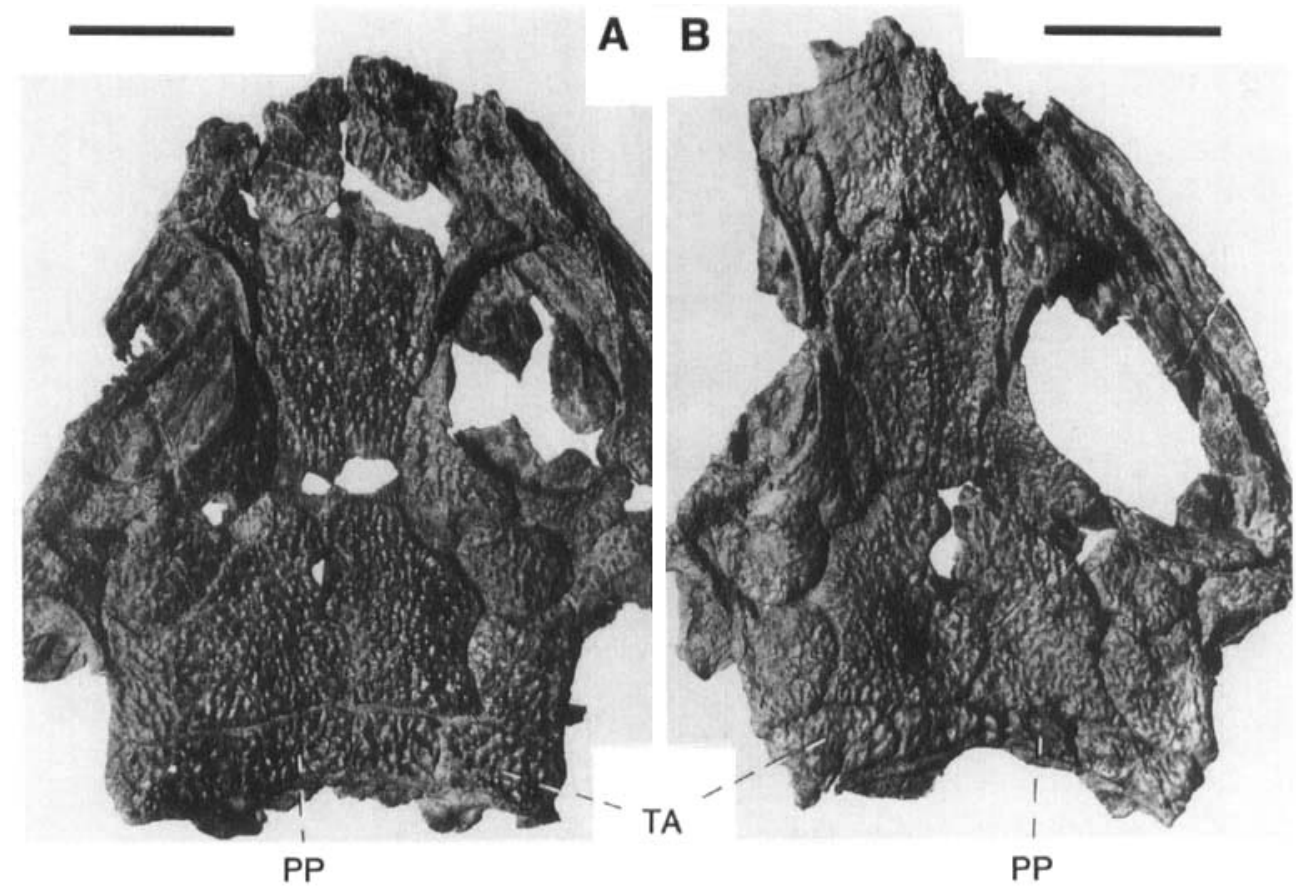

Figure 9. Discosauriscus austriacus (Makowsky, 1876). A, D 74; B, D 81. Skulls in dorsal view. Scale bars $=10 \mathrm{~mm}$. (For key to abbreviations see p. 270.)

additional specimens of $S$. sanjuanensis and three specimens of $S$. baylorensis. The statistical analysis and Figs 7,8,9 and 11 indicate that the length or width of the postparietal (and the tabular) does not always change proportionally with other length characteristics. For example, in two large specimens with different width of skull table-K 16 ('narrow' skull, Fig. 8A) and K 323 ('broad' skull, Fig. 11), the length of the post parietals is about the same. Additionally, as already mentioned, on the specimen D 81 (with approximately the same width of the skull table as in D 74) the length of the postparietal and tabular is laterally enlarged in the direction from the median plane (Fig. 9).

Although some possibilities for discriminating the collection of Moravian Discosauriscus specimens into two groups were found on the basis of parameters such as postparietal length, no important morphological differences have been ascertained up to now. However, the differentiation into groups based on shape variability of the skull does not justify classification into genera or species. Alternative explanations could be sexual dimorphism or other phenomena. Jolicoeur (1959) found on the basis of measurement of skulls of the wolf (Canis lupus) that Arctic wolves do not overlap with those of the Rockies (with the exception of one juvenile specimen). Similar measurements of skulls have been performed for the detection of intraspecies differentiation in other Recent animals (Baker, 1980; Gibson, Baker \& Moeed, 1984). On the other hand, however, in measuring the shape changes of bones the characteristics obtained (e.g. component scores) can overlap in multivariate analyses in several species (e.g. Strauss, 1985). This means that the existence of two or more species of Moravian discosauriscids cannot be excluded. Such a distinct separation as Humphries et al. (1981) found among different species was not confirmed by us 

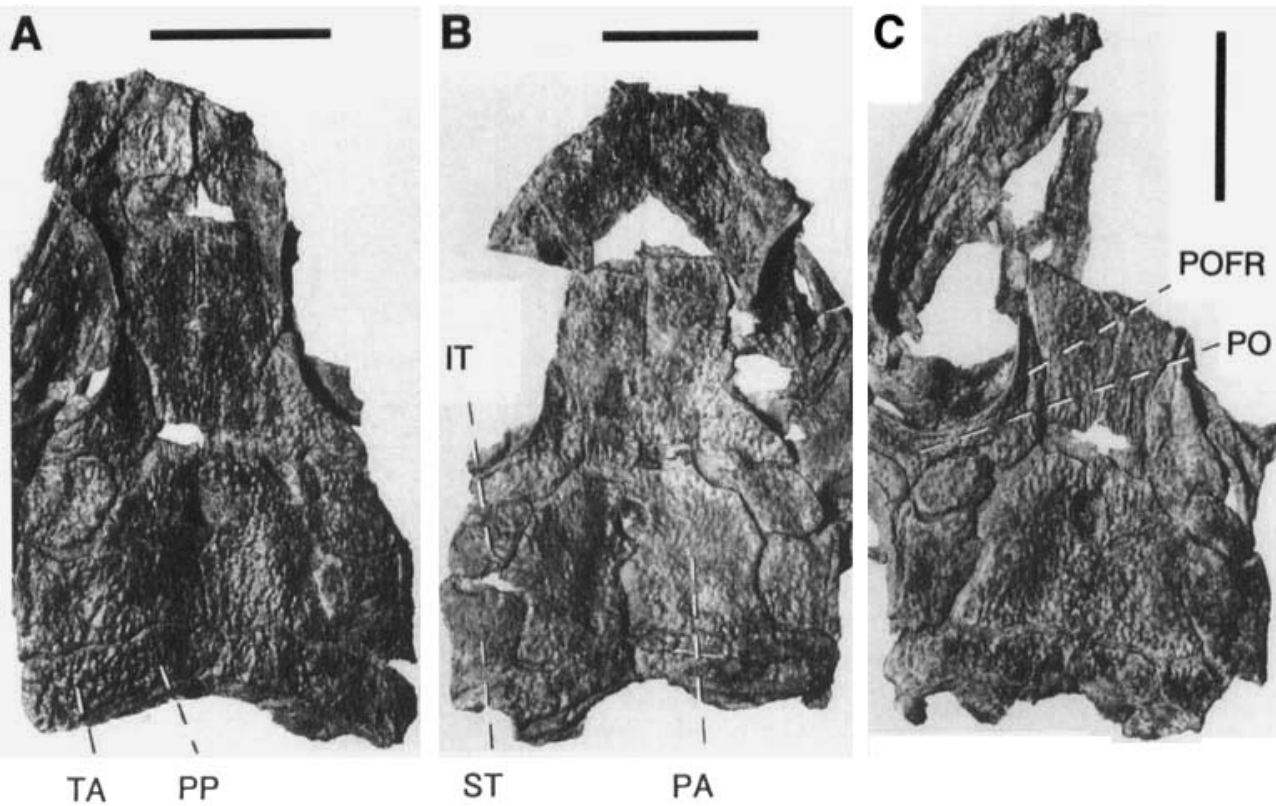

Figure 10. Discosauriscus austriacus (Makowsky, 1876). A, D 20; B, D 45; C, D 80. Skulls in dorsal aspect. Scale bars $=10 \mathrm{~mm}$. (For key to abbreviations sec p. 270.)

using similar techniques. More distinct morphological differences should exist for the differentiation of several species.

In connection with these proportional changes it is notable that within a given region of approximately proportionally equal skulls, the relative size of individual bones can vary. Thus, within the parietal table in D 20, D 45 and D 80 it is possible to observe the elongation of the supratemporal at the expense of the intertemporal (Fig. 10). The relationship of these two bones can differ on the right and left sides of skull of one specimen. However, sometimes the size of two bones may differ in dorsal view but be dependent only on the course of the suture between their ornamented surfaces (e.g. in parietals, Fig. 9B). Such differences should be regarded as individual variability, which, from this aspect, is relatively great in the Moravian Discosauriscus (this will be discussed in a later work).

The above results of statistical analysis and the absence of distinct morphological differences indicate that, at present, there exists no reliable criterion for the differentiation of more than one taxon within the Moravian discosauriscids. Proportional differences alone are not sufficient and cannot be considered to be taxonomically significant. Therefore the Moravian discosauriscids (and probably the other specimens, hitherto assigned to Discosauriscus and Letoverpeton) will be considered as one genus and species: Discosauriscus austriacus (Makowsky, 1876).

The presence of differences in skull proportions and the absence of distinct morphological differences are recorded in other early tetrapods, where more specimens are present (e.g. in embolomeres such as Proterogyrinus, Holmes, 1984, Archeria, Clack, 1987 or in Acanthostega, Clack, 1988). According to these authors, in none of these cases can the presence of more taxa be excluded but the absence of distinct morphological differences does not enable us to distinguish them; they 


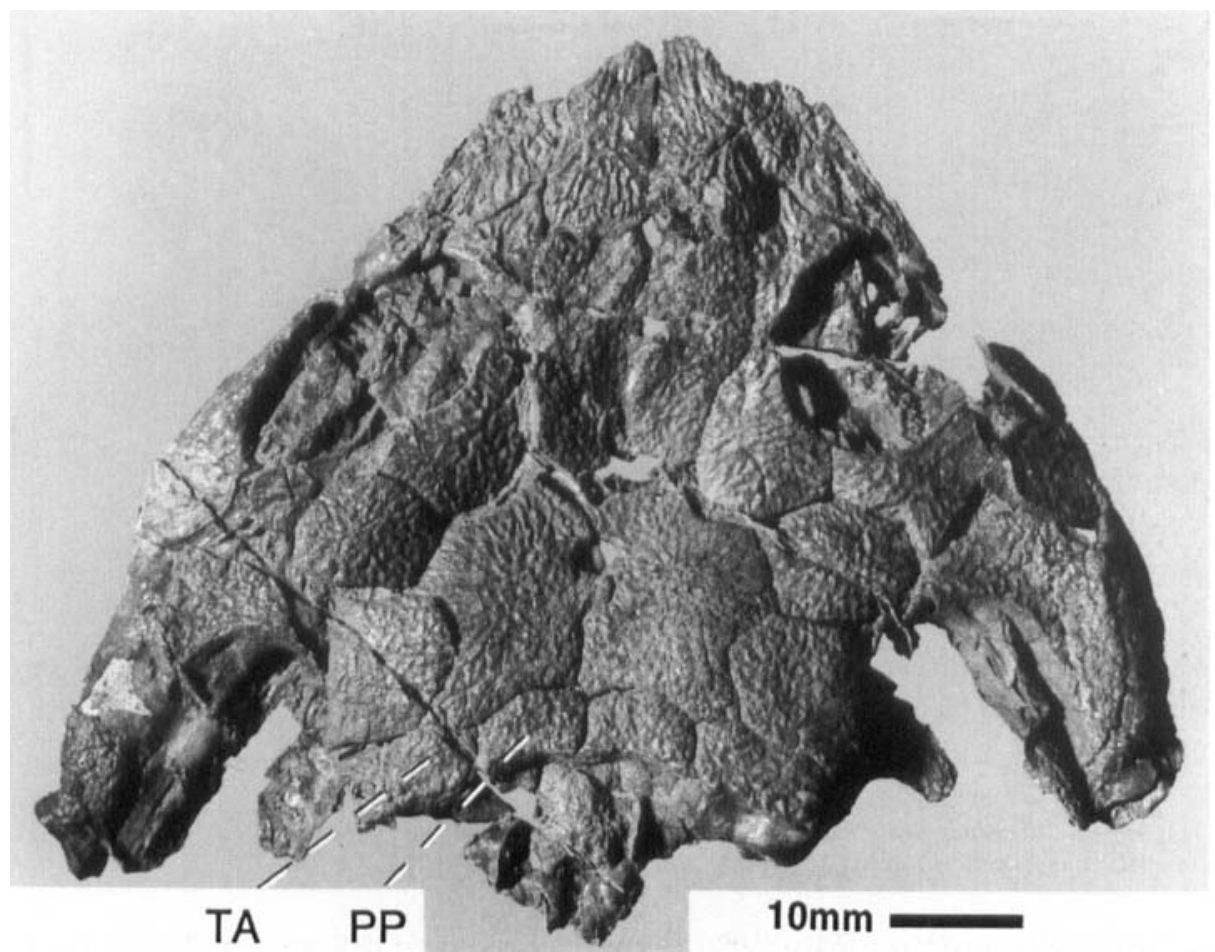

Figure 11. Discosauriscus austriacus (Makowsky, 1876), K 323. Skull in dorsal aspect. (For key to abbreviations see p. 270.)

are understood as individual variation in skull proportions. However, the existence of morphological trends was recorded in the genus Seymouria (Berman, Reisz \& Eberth, 1987), which is morphologically close to discosauriscids.

Systematic position. On the basis of above data it follows that from the previously described and the new material from the Boskovice Furrow in Moravia it is possible to recognize only one genus and species: Discosauriscus austriacus (Makowsky, 1876). Ivakhnenko (1987, cf. Ivakhnenko, 1981) came to the same conclusion, although on the base of completely different criteria. The synonymy (see also Ivakhnenko, 1987) is as follows.

\section{Discosauriscus austriacus (Makowsky, 1876)}

1876 Archegosaurus austriacus-Makowsky, p. 155

(For the complete synonymy up to 1952, see Špinar, 1952.)

1952 Discosauriscus pulcherrimus-Šspinar, p. 27

1952 Discosauriscus potamites-Špinar, p. 50

1952 Letoverpeton moravicum-Spinar, p. 61

1952 Letoverpeton austriacum-S Śpinar, p. 73

1981 Discosauriscus permianus-Ivakhnenko, p. 117

1989 Discosauriscus pulcherrimus--Werneburg, p. 34

1989 Discosauriscus aff. pulcherrimus-Werneburg, p. 34

1989 Letoverpeton austriacum-Werneburg, p. 35

1989 Letoverpeton moravicum-Werneburg, p. 35 
For diagnosis, see Špinar (1952), Ivakhnenko (1987) and Werneburg (1989). However, these diagnoses will be revised on the basis of anatomical studies of the new material of Discosauriscus presented in this paper.

\section{ACKNOWLEDGEMENTS}

We are indebted to Dr A. R. Milner (Birkbeck College, London) for reading the manuscript and linguistic correction. We are grateful to Prof. P. Jolicoeur (Université de Montréal, Montreal) for reading the part of the manuscript concerning the statatistical analyses. We thank also Mrs Z. Sulavíková for typing the manuscript.

\section{REFERENCES}

Baker AJ. 1980. Morphometric differentiation in New Zealand populations of the house sparrow (Passer domesticus). Evolution 34: 638-653.

Berman DS, Reisz RR, Eberth DA. 1987. Seymouria sanjuanensis (Amphibia, Batrachosauria) from the Lower Permian Cutler Formation of north-central New Mexico and the occurrence of sexual dimorphism in that genus questioned. Canadian Journal of Earth Sciences 24: 1769-1784.

Broili F. 1904. Permische Stegocephalen und Reptilien aus Texas. Palaeontographica 51: 1-120.

Clack JA. 1987. Pholiderpeton scutigerum Huxley, an amphibian from the Yorkshire coal measures. Philosophical Transactions of the Royal Society of London (B) 318: 1- 107.

Clack JA. 1988. New material of the early tetrapod Acanthostega from the Upper Devonian of East Greenland. Palaeontology 31: $699-724$.

Fritsch A. 1879. Neue Übersicht der in der Gaskohle und den Kalksteinen der Permformation in Böhmen vorgefundenen Tierreste. Sitzungsberichte der königlichen böhmischen Gesselschaft der Wissenschaften (Prag 1879): $184-195$.

Fritsch A. 1883. Fauna der Gaskohle und der Kalksteine der Permformation Böhmens. Selbstverlag, Prag 1883, Bd. I: $1-182$.

Gibson AR, Baker AJ, and Moeed A. 1984. Morphometric variation in introduced populations of the common mynah (Acridotheres tristis): an application of the jacknife to principal component analysis. Systematic Zoology 33: 408-421.

Heaton MJ. 1980. 'The Cotylosauria: a reconsideration of a group of archaic tetrapods. In: Panchen $\mathrm{AL}$, ed. The terrestrial environment and the origin of land verlebrates. London: Academic Press, 497-551.

Holmes R. 1984. The Carboniferous amphibian Proterogyrinus scheelei Romer, and the early evolution of tetrapods. Philosophical Transactions of the Royal Society of London (B) 306: 431-527.

Humphries JM, Bookstein FL, Chernoff B, Smith GR, Elder RL, Poss SG. 1981. Multivariate discrimination by shape in relation to size. Systematic Zoology 30: 29l-308.

Ivakhnenko MF. 1981. Discosauriscidae from the Permian of Tadzhikistan. Paleontological Journal 1: 114-128. [In Russian.]

Ivakhnenko MF. 1987. Permian parareptiles of USSR. "Nauka", Trudy paleontologischeskovo instituta $A \mathcal{N}$ 223: 1-160. [In Russian.]

Jolicoeur P. 1959. Multivariate gcographical variation in the wolf Canis lupus L., Evolution 13: $283-229$.

Jolicoeur P. 1963a. Bilateral symmetry and asymmetry in limb bones of Martes americana and man. Revue Canadianne de Biologie 22: 409432.

Jolicoeur P. 1963b. The degree of generality of robusiness in Marles americana. Growth 27: 1-27.

Jolicoeur P. 1963c. 'The multivariate generalization of the allometry equation. Biometrics 19: 497-499.

Jolicoeur P. 1984. Principal components, factor analysis, and multivariate allometry: A small-sample direction test. Biometrics 40: 685-690.

Jolicoeur P, Mosimann JE. 1960. Size and shape variation in the painted turle. A principal component analysis. Growth 24: 339-354.

Klembara J, Meszároš \$. 1992. New finds of Discosauriscus austriacus (Makowsky, 1876) from the Lower Permian of Boskopvice Furrow (Czechoslovakia). Geologica Carpathicaal 43: 305-312.

Kuhn O. 1933. Labyrinthodontia. In W. Quenstedt (Ed.), Fossilium Catalogus, I. Animalia 61: 1-114.

Kuznetsov V, Ivakhnenko MF. 1981. Discosauriscids from the Upper Palacozoic of South Kazakhstan. Paleontological Journal 3: 102-110. [In Russian.]

Makowsky A. 1876. Über einen neuen Labyrinthodonten "Archegosaurus austriacus nov. Spec.". Sitzungsberichte der kaiserlichen Akademie der Wissenschaft 73: 155-166.

Mosimann JE, James FC. 1979. New statistical methods for allometry with application to Florida redwinged blackbirds. Evolution 33: 444459. 
Romer AS. 1947. Review of the Labyrinthdontia. Bulletin of the Museum of Comparative Zoology, Harvard College 99: $1-368$.

Sarmanová J, Luknsovín A. 1985. Methods of cluster analysis Praha: SNTL.

Smithson TR. 1985. The morphology and relationships of the Carboniferous amphibian Eoherpeton watsoni Panchen. Zoological Journal of the Linnean Society 85: 317-410.

Sommers KM. 1986. Multivariate allometry and removal of size with principal component analysis. Systematic Zoology 35: 359-368.

Spinar ZV. 1952. Revise některých moravských Diskosaurischidů (Labyrinthodontia). Rozpravy Ústtedního ústavu geologického 15: 1-115.

Steen MC. 1938. On the fossil Amphibia from the Gas Coal of Nýřany and other deposits in Czechoslovakia. Proceedings of the Zoological Society of London (B) 108: 205-283.

Strauss RE. 1985. Evolutionary allometry and variation and body form in the South American catfish genus Corydoras (Callichthyidae). Systematic Zoology 34: 381-396.

Vaughn PP. 1966. Seymouria from the Lower Permian of southeastern Utah, and possible sexual dimorphism in that genus. Journal of Paleontology 40: 603-612.

Werneburg R. 1985. Zur Taxonomie der jungpaläozoischen Familie Discosauriscidae Romer 1947 (Batrachosauria, Amphibia). Freiberger Forschungshefte (C) 100: 117-133.

Werneburg R. 1988. Die Amphibienfauna der Oberhöfer Schichten (Unterrotliegendes, Unterperm) des Thüringer Waldes. Veröffentlichungen des Naturhistorischen Museums in Schleusingen 3: 2-27.

Werneburg R. 1989. Labyrinthodontier (Amphibia) aus dem Oberkarbon und Unterperm Mitteleuropas-Systematik, Phylogenie und Stratigraphie. Freiberger Forschungshefte (C) 436: 7-57.

White TE. 1939. Osteology of Seymouria baylorensis Broili. Bulletin of the Museum of Comparative Zoology, Harvard College 85: 325-409.

\section{ABBREVIATIONS USED IN FIGURES}

$$
\begin{aligned}
& \text { FR-frontal } \\
& \text { IC-interclavicle } \\
& \text { IS-ischia } \\
& \text { IT-intertemporal } \\
& \mathrm{IT}_{1} \text {-intertemporal } 1 \\
& \mathrm{IT}_{2} \text {--intertemporal } 2 \\
& \mathrm{JU} \text {-jugal } \\
& \text { LAC--lacrimal } \\
& \text { MX - -maxillary } \\
& \text { NA-nasal } \\
& \text { PA-parietal }
\end{aligned}
$$

$$
\begin{aligned}
& \text { PFR-prefrontal } \\
& \text { POFR-postfrontal } \\
& \text { PMX-premaxillary } \\
& \text { PO_postorbital } \\
& \text { PP-postparietal } \\
& \text { QJU-quadratojugal } \\
& \text { SMX--septomaxillary } \\
& \text { SQ squamosal } \\
& \text { ST-supratemporal } \\
& \text { TA-tabular }
\end{aligned}
$$

